\title{
THE THEORY OF PARTONIZED GOODS IN THE OPTICS OF COMPARATIVE METHODOLOGY
}

\author{
Aleksander RUBINSTEIN ${ }^{1}$ \\ Institute of Economy of the Russian Academy of Science
}

\begin{abstract}
The present study focuses on the methodological aspects of the Theory of patronized goods, modifications of two liberal principles of the Austrian school, incorporated into mainstream economic theory - "methodological subjectivism" and "methodological individualism", as well as the standard axiom of "homogeneity of economic agents". The paper discusses some modifications to these assumptions and their various combinations that form the basis of a number of theories that justify state activity. Analysis of the basic premises of the theory of public goods and merit goods, and the concept of libertarian paternalism allowed the author to suggest that from the point of view of methodology, these theoretical constructions are particular cases of the Theory of patronized goods based on "methodological subjectivism", "methodological relativism" and "the principle of heterogeneity". In the Theory of patronized goods they are integrated in the form of supposition that every person depending on the level of his understanding and his value judgments acts subjectively optimally in the given circumstances; in the principle of utility complementarity, according to which there may be a group interest alongside with the individual interests of the group members; and in the form of two irreducible to each other branches of formation of public interest-market and political.
\end{abstract}

\section{KEY WORDS}

patronized goods, public goods, meritoric, libertarian paternalism, methodological subjectivism, methodological relativism, heterogeneity, normative interests

\section{JEL CLASSIFICATION}

D01

\section{INTRODUCTION}

The present paper represents author's methodological reflections in the tideway of "Economic sociodynamics" and "Theory of Patronized Goods" (Гринберг, Рубинштейн (2008, 2010), Grinberg, Rubinstein (2010), Рубинштейн (2008, 2010, 2012)). This year Economic Sociodynamics marks its fifteenth anniversary. Throughout these years it has been developing, it's authors cooperatively and individually have published over ten books, multitude of articles and reports, delivered at Russian and international conferences; a sub-theory - "Theory of Patronized

\footnotetext{
${ }^{1}$ Correspondence address: prof. Aleksandr Rubinštejn, DrSc., CSc., Ph.D.; arubin@aha.ru: Institute of Economy, Russian Academy of Science, Moscow, Russia
} 
Goods" has appeared, and a number of independent dissertation researches carried in various scientific canters of Russia are based on its fundamental principles and retain their relevancy forming foundation for problem discussion either face-to-face at conferences and seminars or at distance via debates in journals.

However, some of my recurrent collocutors and distinguished opponents with their doubtless talents and competences have some difficulties in adequate perceiving of some of the Theory of Patronized Goods' principles. And contrary, a number of scientists brought up within Soviet economic science who retained the leftism of their views, without looking deep into the true meaning of the elaborated theory, easily accept its main conclusions connected with normative social interest and need for state activity. While modern economic theory bases itself on the ideology of liberalism, the pro-Soviet nostalgia-stricken political economists advocate socialism-based views.

Personally, I am more inclined to support the liberal values, freedom of choice and market economy; however, the standard theory based on a number of fundamental implications (methodological individualism, principle of rational behavior, homogeny of economic agents, etc.) does not give answers to many important questions. At the same time, the attempts to interpret Theory of Patronized Goods within the boundaries of non-classic axiomatic create insoluble contradictions. This is best shown by my benevolent opponents who try to adapt Economic sociodynamics and Theory of Patronized Goods to the framework of general course of economic theory. Thus, the necessity to go back to discussion of the initial assumptions became apparent. The additional impulse was given by the articles of V.Polterovich on the crisis of economic theory and general social analysis ((Полтерович $(1998,2011))$, a number of publications in the journal "Voprosy Economiki", which reveal the results of behavioral economics within the context of economy science development (Белянин (2003), Коландер (2009), Хэндс (2012)), reports at "round table" "New approaches to methodology of economic analysis" at the II Russian economic congress (Suzdal, 2013) and also several articles in "Social Sciences and modernity" journal, that organized discussions on topical issues in theoretical economics(Либман (2013), Тихонова (2013), Урнов (2013)) $)^{2}$.

There is yet another reason of my interest in methodological issues. The thing is that starting from the 30s of the XX century theoretical economics has been developing in the conditions of growing pressure of mathematic methods and models, which on the one hand made me understand really a $\operatorname{lot}^{3}$, but on the other, required the introduction of very stringent assumptions that in most cases do not follow from the economic content of the simulated process. This gap was accumulating and became the subject of analysis of several theoretical studies as well as numerous empirical studies that demonstrated that economics was "pressed" in the neoclassical paradigm, which, according to de Soto, "is stagnating because of its completely unrealistic axioms, static nature, and its formal reductionism " (de Como (2008, c. 1)).

Economic Sociodynamics and the Theory of patronized goods were born in an attempt to overcome this methodological "obstacle". They are based on a modification of a number of neoclassic premises. I mean two liberal principles of the Austrian school, incorporated into mainstream

\footnotetext{
${ }^{2}$ Let me take this opportunity to thank the editorial board of the journal "Social Sciences and Modernity" that gave me a chance to start the discussion on theoretical and methodological aspects of Economic Sociodynamics and the Theory of patronized goods (Рубинштейн (2012, с. 13-34)).

${ }^{3}$ Several years ago, in a conversation with Kenneth Arrow, I raised the issue of the mathematization of economics and a certain loss of real economic content in mathematical models. To which Arrow said: "the economy is so complex that without mathematics that simplifies the real world, it is impossible to understand" (Гринберг, Рубинитейн (2010, с. 9-10)).
} 
economic theory - "methodological subjectivism " and " methodological individualism "4, and the axiom of "homogeneity of economic agents". Adhering to methodological subjectivism and being a longtime critic of "trite methodological individualism "(de Como $(2009$, c. 3)), I assume the practicability of its replacement with a more general ontological principle used in a number of scientific disciplines, including linguistics and sociology. We are talking about some sort of synthesis of individualism and holism - the "methodological relativism"(Лещак $(2002$, c. 38-42)). Within the Economic Sociodynamics it is concretized as the principle of complementarity of utility according to which there can be a group interest along with the individual interests of the group members. I see this as generic properties of the Theory of patronized goods, its object of study being private initiative and state activity aimed at realization of individual and public interests. Based on this viewpoint I consider premises for rational individual behavior and homogeneity of economic agents.

Let me also note that the premises of rational behavior, methodological individualism, and homogeneity have been revisioned in a number of different theoretical constructions. Without any attempt to provide an exhaustive analysis, in this work we will consider some modifications of the stated premises and their various combinations that constitute the methodological basis for a number of theories that substantiate state activity. We will talk about the corresponding comparison of welfare economics, theory of public goods and merit goods, and the concept of mild or libertarian paternalism with the Theory of patronized goods.

\section{METHODOLOGICAL SUBJECTIVISM}

Let us start with the fundamental assumption of the theory of welfare - the principle of rational behavior, which unites Austrian "methodological subjectivism" where individual preferences are taken for granted and non-classical assumption that every individual chooses the best option that optimizes his welfare. The "invisible hand" which provides public welfare defined as the aggregated welfares of the individuals does all the rest. If the losses in public welfare occur, they are explained by the "market failure" and account for government interventions aimed at their elimination ${ }^{5}$. Without elaborating on this well-known scenario, I would like to point out the essence - strongly rational behavior of individuals who maximize their welfare is one of the principle assumptions of the stated theory.

"Our ignorance is infinite and sobering" (Эволюционная... (2000, p. 299)). The words of Karl Popper have "sobering" effect on most of the models of human behavior in economy as well as their basic assumptions including the one of rationality. "The results of researches carried during the last quarter of the century show that people do behave consistently but in a way that substantially differs from the variants predicted by the standard model of rationality" (Стиглиц (2011, p. 3000)).Regular critics of this "simplifying abstraction", initiated probably by Thorstein Veblen, have accompanied this ontological principle throughout its history. The first significant revision of the principle of rationality is connected with the works of John Katona

\footnotetext{
4 Among the six principles that "an economist trained in the tradition of the Austrian school should adopt," Fritz Machlup noted "methodological subjectivism" and "methodological individualism"(Machlup (1982, P.42), Заостровиев (2007, с. 70)). See also: (Вольчик (2007, с. 103-104), де Cото (2009, с. 3-4)).

${ }^{5}$ In opposition to the concept of "market failure" economists increasingly turn to "government failure" research, in which instead of individual behavior the analytical scope moves to the influence on governmental activity of the established legislative norms, social institutes and current political priorities that may lead to worse results than before interfering into market process. Apart from earlier works of Krueger (Krueger $(1974,1990)$ ), a number of books within the last decade should be noted (Tullock, Seldon, Brady (2002), Winston(2006)) as well as an ample article (Padblzuн, Энтов (2012)).
} 
(Katona (1951)) and Herbert Simon (Simon (1955)). Katona wrote challenging the assumption of rational behavior, “... we mustn't assume from the start that rational behavior indeed exists. While describing and classifying different reactions as well as circumstances which generate them, we should always wonder if these reaction have right to be called "rational", and if so than to which extend" (Katona (1951, s. 16). H.Simon has even more definite opinion challenging the very ability of people to adequately evaluate their choices (Simon (1955), Саймон (1993)). He also introduced to scientific discourse the established category of "restricted rationality" (Simon $(1955,1957))^{6}$.

Simon's works gave rise to skeptical views of rationality postulate and dependence of individual behavior on aspiration to maximize their welfare. A certain weakening of this initial assumption found its way in theories of public goods and merit goods in which the taboo on irrational individual behavior was actually lifted. And while within the theory of public goods the possibility of "wrong" decisions was acknowledged indirectly - to the "free rider" behavior Paul Samuelson added "a false signal of individuals on the lack of demand for public welfare" (Samuelson (1954), Самуэльсон (2004)), in meritorics Richard Musgrave describes standard cases of irrational behavior(Musgrave (1959, 1994), Масгрейв, (2009)).

At that in compliance with specific qualities of "public goods", individuals consciously (according to Samuelson) conceal their preferences. In meritorious environment, a corrupted signal about demand appears due to non-conscious irrationality of behavior. This refers to "pathologic case", "Odysseys" infirmity", "irrationality of the poor" and "common needs" - systematically arising situations when individuals are not able to act in their best interests. Progressing skepticism as for people's optimizing behavior regardless the definition of their interests ${ }^{7}$ created meritorics with its legitimate interference into consumer preferences and "paternalistic policy" (Musgrave (1959, p. 13), D'Amico (2009)), based on the methodological technique of "doublethink". The case is that in theory of public goods and in meritorics, which allow for irrational behavior of individuals, one has to discard both components of category of rationality - optimizing behavior and Austrian subjectivism. By admitting the very fact of irrational behavior of individuals, we are also forced to keep in mind those actions that could be called rational. This approach inevitably leads to supposition of at least two preference systems, two "standards of evaluation which under particular circumstances may exclude each other in a way that utterly different, even opposite actions are considered optimal" (Tietzel, Muller (1998, s. 116)). Moreover market-defined preferences often appear to be false (Самуэльсон (2004, с. 375)), and the true preferences conforming to some "legal standard" have only "reflective character" (Brennan, Lomasky (1983, p. 183-206)).

The model of Thaler and Shefrin that postulates "split personality" of individual by acting simultaneously as both tempter's victim (me-executor) and his rational antipode and "creator's pride" (me-programmator) adds nothing new to the problem. While "executor" tends to act egoistically and shortsightedly, "programmator" aspires to realization of long-term and enlightened interests (Thaler, Shefrin $\left(1981\right.$, p. 392-406))..$^{8}$ Thomas Schelling characterizes this as a situation where "people act like two different selves and run the show in turns" (Schelling (1984)). Quite

\footnotetext{
${ }^{6}$ I cannot say that I support the following Giovanni Dosi opinion, "I do not fancy the expression restricted rationality as it has implications to some Olympic rationality from the height of which we can judge upon how restricted is the restricted. However in the changing and complicated environment it is often impossible to define such perfect rationality in principle" (Дози (2012, с. 40), Dosi et al (2005)).

7 It's way back to Alfred Marshall who in his "Principles of political economy" underlined that egoism was not the only "operant motive of human activity" (Маршалл (1983,c. 77-79)). Howard Margolis who was one of the first to expand the notion of rationality by including altruism, came up with "fair-share model", or F-S model based on the principal of personality dualism, the presence of two "selves": egoist self and altruist self (Margolis (1982, p. 14)). For more details consult (Рубинштейн (2012, с. 21, 23)).

${ }^{8}$ This work first published in "work notebooks" (Shefrin, Thaler (1978)), goes back to earlier research in the field of experimental psychology, in which Richard Shefrin and Walter Schneider while studying the hypothesis of human being possessing two cognitive system discovered "battle between reason and intuition" - the prototype of the future models with the multiplicity of "Self" (Schneider, Shiffrin $(1977 a, b))$.
} 
understandingly, these circumstances give rise to the problem of self-government as in particular situation a person may act differently from what his more profound and multifold estimation of consequences could tell him (Koboldt (1995, s. 13)). The main fact about detabooing of irrational behavior is that it also means rejection of the principle of methodological subjectivism, a move to multiplicity of "Self", the use of governmental paternalistic policy aimed at supporting such a "Self" that insures compliance with normative standard. It is quite natural therefore, that the welfare economics, which grounds itself on the principle of methodological subjectivism and consumer sovereignty, is traditionally opposed to paternalism. However, as time zips along, during the last 3040 years numerous researches in the field of behavioral and experimental economy appeared, that registered, though in laboratory conditions, systematical recurrent cases of irrational behavior of individuals. In this context the necessity of revision of rationality assumption increasingly gains recognition (Коландер (2009), Хендс (2012), Ананьин (2013, с. 23), Ольсевич (2013, с. 11-17)).

While the theories of public goods and merit goods following Simon viewed restricted rationality as theoretical abstraction, psychologists and behavioral economists having conducted a variety of experiments obtained empirical proof of individuals' irrational behavior. As a result by the beginning of the XXI century an impressive collection of "anomalies" was accumulated - "effect of initial endowment", "status-quo prejudices", "anchor effect", "ambiguity evasion" which show the real life examples of individuals' behavior that alter from the prognoses of standard theory (Kahneman, Tversky (2000), Thaler (2000), Канеман, Тверски (2003), Павлов (2007, 2011)). This challenge required an adequate answer.

With that just criticizing meritorics and its "methodological weaknesses" (Schmidt (1988), Tictzel, Müller (1998), Müller, Tietzel (2002)) without any positive program is not enough anymore. Empirical facts that go beyond standard theory of welfare are in need of interpretation. It should be noted however that in this area behavioral economists just elaborated the meritorious argumentation based on the multiplicity of "Self" reinforcing it and turning into their main methodological technique $^{9}$ (Thaler, Shefrin (1981), Sunstein, Thaler (2003)). In other words they also followed the track of rejecting the principle of "methodological subjectivism" thus preserving and developing the meritorious trend in attempts to settle the argument between theoretical assumption of rationality and the realia of irrational behavior.

I do not wish however to overestimate the scale of changes in economics. Some economists are still quite reluctant towards revision of the assumption of rational behavior of individuals, "If it is possible to accept the irrationality of human's nature, it's possible to accept anything ${ }^{10 "}$. Regardless a doubtful flatness of the expression, it seems true that meritorics and behavioral economics's critique of rationality principle just highlights some exceptions within the models of rational choice that are in need of further theoretical generalization.

My perception coincides, though not completely with position of Vernon Smith, "In the latter case we can often explain the data by changing the original models. As a result we deepen the notion of rationality and simultaneously coordinate data with the models; improved normative models forecast the experimental result with more precision" $(\text { Smith }(1991, p .878))^{11}$. In other words, the

\footnotetext{
9 This resembles John Rawls' "veil of ignorance" which at its time became the main methodological technique for constitutional economy of James Buchanan. In either case we encounter with the examples of "insurmountable dualism of economics" (Автономов (2013, с. 6)), or as quoted by Avtonomov, with dilemma of "strictness and realism" (Mayer (1993)).

${ }^{10}$ Special report "New paternalism. Amiable government" published in Economist journal in April, 2006 gives a very detailed review of different opinions on behavioral economics and "sacrificing" the principle of rationality (http://www.economist.com/node/6768159).

${ }^{11}$ Smith's position on this issue is very similar to Milton Friedman attitude towards prerequisites of theoretical models which significance is defined by their prognostic success (Friedman (1953)).
} 
deepening of the notion of rationality that can be interpreted as weakening of presupposition allows not only to correct but also to improve the results of such models. I mean easing the standard regulations of individuals' preferences and in the first place consideration of the established institutional environment and external factors, which influence these preferences.

The question if it is necessary to discard both of these constituents of the category of rationality while explaining the irrational behavior of individuals still remains the main issue. I think that there is no such necessity. Remaining within the framework of "methodological subjectivism" with its demands to take the individual preferences for granted, it is still possible to look for the solution in other rendering of assumption on optimizing behavior of individuals. ${ }^{12}$ The case is that from the perspective of "methodological subjectivism" each person within his understanding and based on his personal values and tastes, demonstrates subjectively optimal behavior. If this behavior is regarded as irrational or restrictedly rational, it means that this evaluation is obtained from exterior, as to individual, source and is based on definition of the so-called "normative standard". People may choose not the best variant in regard to the normative standard due to many circumstances including meritorious deficiency in knowledge, willpower or resources. Meritorics and behavioral economics as well as libertarian paternalism (Sunstein, Thaler (2003, 2008), Camerer et al. (2003) originated from them assume that the activity of state aimed at the change of the established circumstances are able to improve the quality of people's behavior and bring their preferences more in line with normative standard. Not entering the discussion so far about normative standard in itself, I would like to note that as a result of state interference that "pushes" individuals towards the right decisions, the "subjectively rational" behavior of individuals takes shape of rational choice and the defined preferences start corresponding to normative standard.

The main advantage of this construction however, according to the leading figures of this movement, lies in the fact that the push- policy resolves differences between paternalism and the freedom of choice (Sunstein, Thaler (2003, p. 1188)). Not fully supporting this categorical statement, I would like to note that the "push strategy" in itself - the tool that comes from meritorics - amounts to creating conditions under which the individual by choosing subjectively best variant for him realizes the normative standard or at least approaches to it. It actually very much resembles John Nash's methodology according to which individuals under suggested circumstances always act "subjectively rationally". However due to inadequate game rules (institutional environment or established circumstances) their actions may lead to individual welfare losses (Майерсон (2010, с. 29)), i.e. empirically observed irrationality (Nash equilibrium). Change in rules of the game in accordance with the same paternalistic understanding of "as it should be" can push individuals towards choosing such dominating strategy, which would put their preferences in compliance with normative standard.

In other words Nash's methodology makes it possible, with the same grounding of state activity, to preserve basic assumption of individuals" "subjective rationality" replacing "doublethink" and multiplicity of "Self" inherent to meritorics and behavioral economics with the provision about ineffective institutional environment. Using Nash's methodology allows easy incorporating of all types of paternalism into the instruments of modernization of institutional environment. At the same time the question of normative standard definition still remains unsolved - how to generate the "as it should be" knowledge, which actually defines the character and concrete directions of institutional modernization that "pushes" individuals towards choosing the "right" strategy.

\footnotetext{
${ }^{12}$ Here attention should be paid to the earlier quoted work of Dosi on evolutionary modeling of nonequilibrium processes in which he explores the possibility of discarding the principle of maximizing behavior of individuals (Дози (2012)).
} 
Let me dwell now on the suppositions of the Theory of Patronized Goods, which follows meritoric line that has absorbed, according to Richard Sturn "traditions of German financial science and public finances after Pigou" (Sturn (2010)). In regard to this, let me repeat the main definition of meritorics: benefits are called meritorious if their demand on the part of individuals lags behind the desired by society and is stimulated by the state. Thus, the very notion of meritorics is directly connected with normative public interest. It is this very aspect of Musgrave's theory that is ultimately important for me, as here the affinity between Theory of Patronized Goods and meritorics most clearly reveals itself. At this point, however similarity comes to an end. Adhering to the Austrian principle of "methodological subjectivism" in the foundations of Theory of Patronized Goods and viewing individuals' behavior as a given, I assume that they act "subjectively rationally" including those situations described by Musgrave and later by behavioral economists. Note that in order to explain their behavior there is no need to resort to the idea of "doublethink", which is rather artificial for economic theory. It is quite enough, as above noted, to reconsider the second constituent of rationality theory - the optimizing behavior of individuals (Table 1).

\section{Table 1 Compartive analysis of modification of rational behavior of individuals}

\begin{tabular}{|c|c|c|c|c|c|}
\hline & $\begin{array}{l}\text { Theory of } \\
\text { welfare }\end{array}$ & $\begin{array}{l}\text { Theory of } \\
\text { public goods }\end{array}$ & $\begin{array}{l}\text { Theory of } \\
\text { merit goods }\end{array}$ & $\begin{array}{l}\text { Concept of } \\
\text { mild } \\
\text { paternalism }\end{array}$ & $\begin{array}{l}\text { Theory of } \\
\text { patronized } \\
\text { goods }\end{array}$ \\
\hline \multirow[t]{2}{*}{$\begin{array}{l}\text { Individual } \\
\text { preferences }\end{array}$} & \multirow[t]{2}{*}{$\begin{array}{l}\text { Methodological } \\
\text { subjectivism }\end{array}$} & False signals & $\begin{array}{l}\text { Corrupted } \\
\text { signals }\end{array}$ & $\begin{array}{l}\text { Corrupted } \\
\text { signals }\end{array}$ & \multirow[t]{2}{*}{$\begin{array}{l}\text { Methodological } \\
\text { subjectivism }\end{array}$} \\
\hline & & $\begin{array}{l}\text { True } \\
\text { preferences }\end{array}$ & $\begin{array}{l}\text { True } \\
\text { preferences }\end{array}$ & $\begin{array}{l}\text { True } \\
\text { preferences }\end{array}$ & \\
\hline $\begin{array}{l}\text { Optimizing } \\
\text { behavior }\end{array}$ & $\begin{array}{l}\text { Complete } \\
\text { rationality }\end{array}$ & $\begin{array}{l}\text { Restricted } \\
\text { rationality }\end{array}$ & $\begin{array}{l}\text { Restricted } \\
\text { rationality }\end{array}$ & $\begin{array}{l}\text { Restricted } \\
\text { rationality }\end{array}$ & $\begin{array}{l}\text { Subjective } \\
\text { rationality }\end{array}$ \\
\hline
\end{tabular}

Let me accentuate that the fundamental difference between the Theory of Patronized Goods and Musgrave's meritorics lies not in the negation of preferences duality but in different understanding of its nature. In my view, such duality is determined by existence of two essentially different subjects with their own preferences, and is far from supposing the same subject double thinking. Therefore the situation described in meritorics and repeated in behavioral economics, when individuals are unaware of "their second thought" while some third party knows very well about it and for individuals' sake stimulate this very "thought", does not change anything meaningful. The ambivalence of individuals' preferences inevitably leads to the existence of external source of their evaluation: apart from the multiplicity of "Self" there appears a judge with his own normative standard, who decides which of the "Selves", is right. Reasoning from this fact, a different treatment of duality of individuals' preferences was introduced in the Theory of Patronized Goods. Let me quote in this regard one of the principles of Roman private law: a wish cannot be claimed unfair - «volenti non fit iniuria». Within this context the basic dilemma between true and false preferences of individuals, that was formulated in the theories of public goods and merit goods and later repeated and intensified by behavioral economists, is false as such. Based on this understanding of "doublethink" model and adhering to the principle of methodological subjectivism, I would like to stress that the Theory of Patronized Goods has at its foundation another assumption explaining the nature of preferences duality. I am referring to the assumption of existence of a certain external source of evaluation, some autonomous bear bearer of preferences that can be treated as normative standard.

\section{NORMATIVE STANDARD}


It is a well-known fact that welfare economics proceeds from complete rationality of agents. I am referring to aspiration of individuals towards maximum realization of their structured and coordinated preferences and choosing from all available alternatives the best variants of behavior. The preferences defined with the help of market mechanisms act as a naturally positive normative standard regardless whether it is the evaluation of a single individual's welfare or the whole society. A.Radygin and R.Entov may have their point saying that "multiple difficulties arise both in defining and correspondent use of information on all participants' preferences and forming the basis for state activity" (Радыгин, Энтов (2012, с. 8)).

It may be supposed that those difficulties are immediately determined by the fact that the basis for state activity (normative standard) has entirely value nature and in fact does not depend on positive preferences of participants. To overcome these difficulties admitting the existence of only market branch in forming public interests that aggregates individual preferences seems to me as completely unreal. I would also like to stress that sometimes unsupported by empirical research hypothesis about rational behavior of individuals as well as inability of standard theory of welfare to account for the results of behavioral economists deteriorate the value of this most important theory of the XXth century.

It is somewhat different for the theory of public goods. The peculiarities of these goods and services that have a non-excludable and non-rival character making individuals give "false signals" about zero demand for a public good due to their egoistic interest, as well as the absence of market mechanism of defining individual preferences gave P.Samuelson the foundation for his theorem "On impossibility". According to it, there is no decentralized solution for production of a public good (Самуэльсон $(2004, c$. 374)). The production volume of such good is determined by the state that sets the "how it should be", i.e. normative standard generated by "ethics expert" (Samuelson (1954, p. 388)). This theory as it appears was the first to offer normative choice that actually settled the conflict between false and true preferences of individuals. As distinct from the Theory of Patronized Goods where the autonomous bearer of preferences defines the normative standard, and the Theory of public goods where this function is performed by samuelsonian "ethics expert", in meritorics and in the concept of mild and libertarian paternalism this supposition is not formulated explicitly. Thus, normative standard in these theories remains as undetermined as are the "true preferences" of individuals. Any attempt to specify the true preferences or at least to decrease the extent of their indefiniteness is based on some vague-sourced knowledge of what is good and bad and "how it should be". Even if we admit subsequent manipulations that preserve greater freedom of individual choice as an effective instrument of state policy, there remains a common for these theories "methodological gap" in respect of definition of normative standard.

It should be said that "state's opacity about the true preferences of individuals" (Schmidt (1988, s. 384)) and the probability of arbitrariness in defining normatively correct preferences (normative standard) have always been the Achilles' heel of meritorics. An old comment of McLure on this drawback (McLure (1968, s. 479)), made as far as forty-five years ago has probably more point than Muller and Tietzel's statement that the state does not necessarily need to know the "true" preferences of individuals (Tietzel, Müller (1998, s. 106)). Such loyalty of meritorics critics can be explained by their adherence to individualistic paradigm. Remaining adherent to "methodological individualism" they assume that normative standard is either totally unnecessary, or is essentially an aggregation of individual preferences (Tietzel, Müller (1998, s. 106)). Within these lines, go multiple tries to reconcile meritorics with methodological individualism (Brennan, Lomasky (1983, s. 183-206), Head (1988, s. 1-37), Priddat (1992, s. 239-259), Koboldt (1995, s. 153)) as well as the references to constitutional economy in which normative standard is defined with the help of consensus of individual preferences, and individuals are viewed as "ultimate source of evaluations" (Buchanan (1986, p. 249)). This approach however runs against evident conflict between "ultimate source of evaluations" and the multiplicity of "Self" inherent to meritorics. While in the theory of welfare, "methodological individualism" used in combination with "methodological subjectivism" 
is a quite natural assumption, in meritorics, which gave up on Austrian subjectivism and allows for two sources of evaluation, or two systems of individuals' preferences, there appears an unsolvable problem of their coordination with this ontological principle. The thing is that the ambivalence of individuals' preferences inherent to Musgrave's theory inevitably leads to appearance of external source of evaluation with its own normative standard. While remaining within methodological individualism, it is necessary to look for the normative standard directly in individuals' preferences. Moreover as different from theory of welfare, in meritorics market mechanism deals solely with "corrupted" preferences of individuals. However only their "true" preferences can claim the role of normative standard and their own definition involves normative standard. At this point, the circle closes with logical loop.

The bottom-line is obvious. Meritorics' renunciation of "methodological subjectivism" and the use of the model of human behavior based on "doublethink" or multiplicity of "Self" de-facto leads to the renunciation of "methodological individualism" as well. In this case, what is left, what methodological suppositions ground this theory? Apart from evidently formulated duplicity of preferences, the theory also has implicit duplicity of treatment of the very individualistic norm. On the one hand, the possibility of existence of corrupted and true preferences of individuals requires external source of evaluation, which poorly comports with methodological individualism; on the other, this theory supposes "on default" that normative standard can be formulated in terms of true preferences of individuals, i.e. within the framework of methodological individualism (Head (1988, s. 27)).

"Do not make a tangle of it, Philipp, for it is the happiness of humankind you are considering" this is epigraph to Kurt Schmidt article (Schmidt (1988, s. 384)), in which he quotes Alfred de Musset from his "Lorenzaccio". This perfectly chosen epigraph, reflecting liberal tradition with amazing precision, registers the "tender point" of meritorics. However eligible to critique, Musgrave's attempts to justify state's intervention and reconcile it with liberal economic theory ${ }^{13}$ gained momentum in the works of behavioral economists, the supporters of mild paternalism. Thinking of the "happiness of the humankind", they agreed that not everything could be given to "invisible hand" that something had to be done by the state by "pushing" people towards right decisions. Within their meaning, society has to give everybody an opportunity to be happy: both to those no real ideas about happiness, and those who do not possess enough means or willpower to make right decisions, and finally to the future generations.

It should be noted that with all the relevance of the concept of libertarian paternalism, it could be viewed only as "a second discovery" of meritorics made by behavioral economists. From the point of view of methodology, mild paternalism is nearly no different from meritorics that presupposes intrusion into customer preferences. Though in this concept describes slightly different factors influencing individual choice not connected with increasing the welfare, it is the "pushing" of individuals towards making normatively right decision which remains essential. In other words, libertarian (Sunstein, Thaler (2003, p. 1188)) and asymmetrical (Camerer et al (2003, p. 1212)) paternalism, which presuppose substitution of direct restriction of individuals' choice with "option on default", retain at their foundation meritorious intrusion into customer preferences.

Using the advances of behavioral economics Sunstein and Thaler in fact repeated paternalistic thesis of meritorics, which among others attracts attention of D'Amico (D'Amico (2009)). It is not hard to realize that paternalism in any shape including libertarian, asymmetrical, and "policy of gentle push" is based on normative standard, on the knowledge of "what should be". According to

13 Public interest in particular is viewed by Musgrave as the result of "transfer into political trust" of the individual preferences. Voting at elections for particular candidate individuals with their vote assign to him the right to express their opinion on what public preferences should be (Рубинштейн (2009c)). 
R. Sugden, for example, libertarian paternalism is "a concept that involves a planner responsible for correlating information about individual preferences and welfare and basing on these data promoting the growth of general welfare" (Sugden (2008, p. 229)).

Commenting on purely meritorious thesis of Sunstein and Thaler on paternalistic compensation for inadequate information, contracted mental capacities and insufficient willpower of individuals (Sunstein, Thaler (2003, p. 1162)), Sugden stresses that "without normative judgments we wouldn't be able to define full-rate information, non-contracted mental capacities, or absolute self-command" (Sugden (2008, p. 232)). In other words, here as well the normative nature of "true preferences" of individuals requires external source of estimation of their welfare that generates "normative judgments" or normative standard, which, however, does not correlate well with individualistic norm. Thus, we can state that in this issue meritorics and mild paternalism have but marginal differences and in fact suffer from the same affliction of incompatibility of the behavioral model of individuals with multiplicity of "Self" with the principle of methodological individualism.

Let me make general conclusion. Researches by behavioral economists led not only to the rediscovery of meritorics, to development of behavioral model of individuals with multiplicity of "Self" and strengthening of normative vector in economic analysis, but also created yet other doubts in absolutization of the methodological individualism principle, according to which any interests of society can be described via individuals' preferences that have sovereign status. To affirm these doubts let me quote the old philosophic law of David Hume - "it is impossible to derive what should be from what there is" as well as mathematical formulation of in fact the same idea in the shape of Arrow's impossibility theorem. Their direct conclusion appears in the statement that paternalistic directives of society and the correspondent normative standard cannot be derived from individuals' preferences that have positive nature.

Now let us speak about the normative standard in Theory of Patronized Goods, in which the paternalistic interference of the state is given ground from the united perspective (Рубинштейн $(2009 a))$. In this respect let me quote Gunnar Myrdal ,"the only way to approach the objectivity in theoretical analysis is to bring our values from darkness to light, realize them, specify them, openly acknowledge them and let them define theoretical research" (Myrdal (1970, p. 55-56)). Such definitive peculiarity of patronized goods is their social utility - the way to meet public interests that form normative standard. This applies both to social merit goods, and to goods and services, which production and consumption are connected with "markets failures".

While applying to the theories of public and merit goods we can consider this regulation as proven, in respect to "market failures" some special comments should be made and some questions answered. For example, how should poverty be treated, which according to Musgrave leads to irrational behavior of individuals and subsequently to ineffective resources allocation? How should we evaluate what is better - either direct losses in welfare from ineffective use of resources without poverty, or no such losses at high level of poverty? Where should various other cases be placed that are treated by different authors either as market flaw, or as "state failure"? According to the definition of this phenomenon, it is always about the situations that are evaluated as unsatisfactory. Namely evaluated by economists based on "normative standard" drawn up by a correspondent theory ${ }^{14}$. An inevitable conventional element in these evaluations has nothing to do with the market mechanism in itself. Moreover, "market failure" is nothing more than a habitual metaphor that masks the neutrality of self-regulation mechanism ${ }^{15}$. The results of its activity cannot be either

\footnotetext{
${ }^{14}$ According to D.Davidson, for example, if there is no opportunity to interpret individual's behavior as "true in respect to our own standards, we have no reasons to consider it rational" (Дэвидсон (2003, с. 197)). Let me stress here that economists evaluate individuals' behavior using their own standards.

${ }^{15}$ I am inclined to consider "state failure" as another metaphor of the same kind. Thus, even democratic organization of society "does not always presupposes a more thorough study of true preferences of population and defining better
} 
"fault", or "true". They become as such only within people's value judgments. ${ }^{16}$ From the Theory of Patronized goods viewpoint markets inefficiency is no different from other situations that are recognized as unsatisfactory. For example, if the considered monopoly or adverse selection is not approved by society, they can be considered as the analogue to equilibrium evaluated as undesired due to growing inequality in wealth distribution. In both situations as well as in the case of individuals whose behavior is treated as irrational, the question is solely about value judgments that reflect normative directives of society in the form of correspondent preferences of the state - the autonomous market subject (table 2).

\section{Table 2 Comparative analysis of normative standard definitions}

\begin{tabular}{|l|l|l|l|l|l||}
\hline & $\begin{array}{l}\text { Theory of } \\
\text { welfare }\end{array}$ & $\begin{array}{l}\text { Theory of public } \\
\text { goods }\end{array}$ & $\begin{array}{l}\text { Theory of } \\
\text { merit goods }\end{array}$ & $\begin{array}{l}\text { Concept of } \\
\text { mild } \\
\text { paternalism }\end{array}$ & $\begin{array}{l}\text { Theory of } \\
\text { patronized } \\
\text { goods }\end{array}$ \\
\hline $\begin{array}{l}\text { Normative } \\
\text { standard }\end{array}$ & $\begin{array}{l}\text { Revealed } \\
\text { preferences }\end{array}$ & $\begin{array}{l}\text { Preferences of } \\
\text { samuelsonian } \\
\text { "ethics expert" }\end{array}$ & $\begin{array}{l}\text { Value } \\
\text { perceptions }\end{array}$ & $\begin{array}{l}\text { Value } \\
\text { perceptions }\end{array}$ & $\begin{array}{l}\text { Normative } \\
\text { preferences } \\
\text { of society }\end{array}$ \\
\hline
\end{tabular}

Thus, normative standard in the interpretation of Theory of Patronized Goods is the reflection of normative interest of society that cannot be reduced to preferences of individuals. The fact of existence of this interest is substantiated with the correspondent initial assumption based on relativistic philosophy. Methodologically speaking, there are two issues imbedded here. First, why is it necessary to renounce methodological individualism and consider the presence of autonomous interest of society as initial assumption? Second, what are "normative preferences of society", what is their nature, essence and mechanisms of formation? Let me elaborate on the first question.

\section{METHODOLOGICAL RELATIVISM}

I have been repeatedly reproached that the existence of public interest irreducible to individual preferences is postulated in Economic Sociodynamics. This is true, but only a part of the truth. What is meant is the replacement of one postulate of the standard theory - methodological individualism - with a more general original assumption. In this respect both methodological individualism, and its substitute "methodological relativism" have the same axiomatic nature. Though my colleague and partner in epistolary discussions A.Liberman draws attention to the inequality of these postulates, reasoning that "it is easier to admit that everything is confined to the actions of well-watched and familiar individuals than to build a more complicated theory", I cannot agree with him.

Surely, it is easier to make such an assumption, but it fails to explain a whole class of phenomena. According to this assumption, for one, it is impossible to define normative standard in theories of public and merit goods, in concept of mild paternalism where the behavioral model of individuals with multiplicity of "Self" is used. Moreover, it would be evidently erroneous to suppose that the existence of public interest irreducible to individual preferences in Economic Sociodynamics and the Theory of Patronized Goods can be combined with methodological individualism. It should be noted that public interests, as a whole as well as the problem of their interrelation with individual preferences are the "all time subjects" wandering through countries and epochs. By the end of the XIX century, two trends in interpretation of public interest were defined. Thus the German tradition

options to satisfy such requirements" (Радысин, Энтов $(2012$, с. 9). The question is again about "better options" value judgements based on personal standards.

${ }^{16}$ Optimality criterion by Pareto is an example of value judgement. 
postulating the interest of society as such (holism) recognized the category of "collective requirements" as a fundamental base for the famous "German finance science". The English tradition in its turn denied the very possibility of existence of interests different from the aggregated individuals' preferences (individualism). In the XX century, methodological individualism became an antithesis to holism, and steadily occupied its place in the main vein of economic theory. This state of affairs however makes me dissatisfied. As I see it, here lies the one of the main hindrances for the development of economic theory and one of the reasons for unreasonable narrowing of general social analysis. The latter conclusion can be formulated inversion ally - renunciation of radicalization of individualism and move towards relativist philosophy give opportunity to form economic methodology with more general assumptions.

In this respect, allow me to give some comments on interpretation of individualism and holism. But first the arguments pro et contra. Albert Schaffle, for example, wrote about the existence of public requirements "that cannot be met by individual members of society" (Schaffle (1873, s. 113)). Karl Menger expresses himself even more definitely, “...not only human individuals that form these unions but the unions themselves have their own nature and thus the necessity of preserving its essence and development - the general requirements that should not be mixed with the requirements of individual members or even with requirements of all members put together (Menger (1923, s. 8)). Alternative perceptions typical for the XX century are found in the works of Paul Samuelson - "I do not suppose the existence of some mystical collective mind that enables enjoyment of using collective consumer benefits..." (Samuelson (1954, p. 387)), Richard Musgrave - "as a group of people as such cannot talk, the question arises who is able to express the feelings of this group" (Musgrave (1959, p. 87)), and Karl Popper - "behavior and actions of such bodies as groups should be reduced to the behavior and actions of individual people" (Пonnep (1992, c. 109)). ${ }^{17}$ Such simple arguments and counterarguments are abundant on both sides. It seems to me however that the time for simple arguments is gone. From the perspective of modern social science with its principal assumption about "background range space" 18 and institutional understanding of socium they do not seem that convincing. In addition, the idea that the bearer of any interest is some animate creature is clearly superficial. Amid the complicating of interconnections between people, the very institutes generate specific interests of particular communities of individuals and society in general. If we involve the games theory tour discussion, another conclusion will become obvious: because of autonomous and self-interested individual decisions, their aggregate can transgress into the state that contradicts to the interests of each individual. In other words, the obtained result cannot always be reduced to the individual utility functions, which also shows that social entity possesses of system properties that individuals do not have. Quite representative in this respect was the discussion on dilemma "individualism-holism" that took place in the second half of XX century (Блауг (2004, с. 100-101), Krimerman (1969), O'Neil (1973)). One of its peculiarities was that the critics of holism were developing methodological individualism from "ontological individualism" not quite on a reasonable basis - from the fact that society consists of people and from the ideas that individuals create all social institutes, while social values are just hypothetical abstractions (Kincaid (1998, p. 295)). This approach however did not gain universal support. "People do not create society", writes Roy Bhaskar, "as it has always existed before them and is an indispensable condition for their activity" (Bhaskar (1989, p. 36)). Blaug also says, "Though at the trivial level ontological individualism appears fair, it does not necessarily define the way we should or should not study collective phenomena, i.e. with methodological individualism" (Блауг $(2004$, c. 101)). At the same time, a general opinion about insufficient reasonableness of transition from "ontological

\footnotetext{
17 According to Mark Blaug "Popper's own works do not give an insight into how decidedly he advocates methodolovigical individualism” (Блауг (2004, с. 100)), moreover Popper did not take part in the famous methodological dispute in the 1950s.

${ }^{18}$ What is meant here is the "background range space" that exists outside of individuals' heads in which their thoughts and words acquire general sense" (Витгенштейн (1994)). I will later come back to this important philosophic statement that gives base for the scientific explanation to the formation processes of social directives.
} 
individualism" to methodological individualism has been formed (Ходжсон $(2008$, с. 45, сн. 3)). In the end of the XX century this discussion moved chiefly to the works of sociologists, the historical "opposition of the extremes" was preserved - methodological collectivism of Emil Durkheim (Дюркгейм (1899), Гофман (2001)) with its demand to view social phenomena as a phenomenon of social entity not reducible to individual actions and methodological individualism of MaxWeber (Вебер $(1980,1994))$ with its directive to view everything through the actions of individuals. However, the main vector of this discussion moved to the sphere of less radical perception of individualism.

Benno Verlen, for example, stresses, "Methodological individualism does not mean denying the existence of collectivities and institutions. Nor does it require accepting that society is nothing more than an aggregate of individuals belonging to it, or that society can be reduced to individual psychology and explaining it in such notions" (Верлен (2002, с. 16)). Joseph Agassi takes quite the same attitude by interpreting methodological individualism in neutral and even appeasing tones (Agassi $(1960,1973)$ ). This all indicates the formation of certain compromise between holism and individualism and moving towards relativist methodology.

Thus Anthony Giddens views methodological individualism on the one hand as a possible alternative to structural sociology, while on the other comes to the conclusion that structural sociology and methodological individualism are not alternative to each other in a sense that by accepting one we have to dismiss the other (Giddens (1984, 2001)). Another English sociologist R. Bhaskar, who thinks that social relations are compatible to both individualist, and collectivist theories, continues this line of reasoning within the framework of relativist methodology (Бхаскар (1991)). French sociologist R.Boudon upholds rather the same position, stressing that methodological individualism is a necessary but not indispensable condition for social research that requires obligatory analysis of macro sociological phenomena (Boudon (p1988), Будон (1999). Hе also places himself closer to the "centre" and expresses a significant reservation, "assimilation of a group to an individual is legitimate only if the group is organized and evidently possesses institutional forms enabling collective decision making" (Boudon (1979)). In this context, the works of Alain Touraine and Michel Crozier should be discussed with their characteristic trait of accepting the doubleness of public life where social structures and individual behavior act as equal and complimentary elements of surrounding reality (Touraine (2005), Kpoзbe $\left(1993\right.$, c. 35-43)). ${ }^{19}$ Methodologically research directives of Tourain and Crozier are quite correspondent to the approach of Giddens and Bhaskar and actually are based on the synthesis of micro- and macrosociological approaches, on holism and individualism without any obligation to choose any as a fundamental principle. It may be supposed that this essentially relativist methodology creates additional opportunities for modern society research and expands the boundaries of economic analysis.

Now it is necessary to discuss a more complicated and more subtle aspect of "holismindividualism" dilemma characteristic for modern philosophy that divides and inseparably complementing analysis of individuals' behavior and functioning of institutions as elements of society as such. In this respect, we should pay attention at the research of Canadian philosopher and culture scholar Charles Tailor. Having displayed one of the possible ways of economic analysis methodology development, he distinguishes the so-called "indecomposably social benefits" that are by nature inappropriate for individual consumption (Тейлор 2001)). They are in essence identical to "social benefits" in Economic sociodynamics and Theory of Patronized Goods, which having no individual utility are capable of meeting irreducible (indecomposable) social requirements (Гринберг, Рубинштейн (2000, с. 47-54), Рубинштейн (2008, с. 93-114)). The main point of Tailor's work however lies not even in the result that has sovereign significance, but in the

\footnotetext{
${ }^{19}$ See the detailed review of modern French philosophy by Paul Ansar publiched in several issues of "Sociological Review" (Aнсар (1995, 1996, 1997)).
} 
argumentation, that substantiates this result. It is a completely different direction of analysis based on methodology of Austrian philosopher Ludwig Wittgenstein, who enriched modern philosophy with categories of thought and language (Витгенштейн (1994, 2009), Болдырев (2008)) and on works of Ferdinand de Saussure, one of the founders of semiotics, who displayed fundamental differences and cyclic connection between language and speech (Соссюр $(2000,2009))$. Using the already mentioned "background range space that exists outside individuals' heads" ${ }^{20}$ and extrapolating it to the relations of people within socium, Tailor not only strengthens the conclusions in favor of intercompatibility of institutions and individual actions, but also, most importantly, introduces into scientific use phenomenon of "general understanding" as a set of "background base of practices, institutions, and judgments"(Тейлор (2001, с. 12)) immanent to society as a social entity. This approach ensured exceeding the "tight scope" of methodological individualism and founded the philosophic base for viewing socium as a bearer of particular properties and even requirements that can be met by "indecomposably social benefits". ${ }^{21}$ Tailor displays Saussure's endless circle and notes, "Speech activities suppose the existence of language, and language is reproduced in speech activities" (Тейлор $(2001$, c. 11)). At some stretch, Saussure's circle can by associative be applied to the pair individuals-institutions: individual interactions should be viewed within the framework of culturally determined institutions, which are reproduced through the actions of individuals. Let me note that here Tailor goes further than the above mentioned sociologists preserving however their characteristic principle of intercompatibility of holism and individualism that corresponds with methodology of relativism used in Economic Sociodynamics and Theory of Patronized Goods. Adhering to this principle enables "breaking free" from atomization of society as it allows for explaining individual behavior with "macro sociological variables" inter alia. Blaug has also pointed this out in application to economic methodology, "it is in principle highly desirable that all holistic concepts, macroscopic factors, aggregated variables were defined in terms of individual behavior were possible. However when it is not possible, let us not fall into silence just because we cannot violate the principle of methodological individualism" (Блауг (2004, с. 103)). John Maynard Keynes probably also discovered such impossibility. It will be recalled that he outputs the key notions of his theory that display macroeconomic characteristic of the system in general from macro phenomena of the same order and not from individual behavior. Unemployment he explains, for example, with insufficiency of cumulative demand, etc. Though the critics of Keynesianism insisted that macro phenomena should be interpreted through microeconomic actions, it looks like their point has not become dominant. The thesis that explanation of social phenomena cannot be reduced to the actions of individuals has also gained a foothold in new institutional economics (Aoki (2001)). The following words of George Hodgson are also appropriate in this context, "Regardless of their centenary rivalry, methodological individualists and collectivists have more common traits than it is customary supposed. Methodological individualism demands that society should be explained from an individual's viewpoint, which makes it lose sight of the key mechanisms of social influence thus accepting goals and preferences of individuals as given. Methodological collectivism explains individual through society and subsequently lacks adequate explanation of how individual goals and preferences can change. The variants of explanation in both methodological strategies are different; however, the results are much the same in essential points" (Ходжсон $(2008$, c. 51)). I do not recollect exactly where I read the following thought, possibly in A.B. Hofman's works, but I clearly remember the essence of it. There are multiple levels of research of society and human realities. The specific character of each level is always there: any researcher under certain circumstances explains individual behavior with social conditions of individuals 'existence, while under the other circumstances he analyses collectives through individual behavior. In other words, the discussion

\footnotetext{
${ }^{20}$ Illustrating Wittgenstein's ideas, Tailor says the following, "Thoughts presuppose and demand the background range space to be the very thoughts they are" (Тейлор $(2001$, с. 10)).

${ }^{21}$ By naming the phenomena of "general understanding" as culture and using Saussure's approach to a wide class of social phenomena Tailor defined its only bearer - society as such.
} 
about "the only true" individualism or holism cannot provide any ontological results. This conclusion reveals the very essence of relativist methodology that allies a number of Russian economists (Автономов (1998), Полтерович (2011), Ливщии (2013), Ореховский (2013)). I needed this little insight to justify the move from the strictly individualistic norm to "methodological relativism". As Blaug said, if possible, social preferences should be viewed as an aggregate of individuals' preferences; when it is impossible, other laws of formation of socium interest should be considered, including historically formed institutions and mechanisms of political system, the peculiarities of interconnection and competition of political elites supported by interests of corresponding social groups and possessing of their own preferences. This directly relates to the normative standard as well, which defines the direction of state's activity in the theories of public and merit goods, concept of mild paternalism and theory of patronized goods.

In the theory of public welfare methodological individualism, in combination with methodological subjectivism, is a natural provision for the formation of normative standard in the shape of market aggregate of individuals preferences; yet in the theories of public and merit goods, as well as in the concept of mild paternalism that all use the behavioral model of individual with multiple "Self", situation looks quite different. The postulated in those theories "true preferences" (read normative standard) are formed, as shown above, by an external source of evaluation. In other words, such "normatively correct" preferences evidently "clash" with methodological individualism. And only denial (according to Blaug) of strict form of individualism in this theories lets defining normative standard based on value judgments of "how it should be". Though it is unclear as for how this knowledge arises, we can conclude that by declaring their adherence to methodological individualism and simultaneously violating this canon, the representatives of these theories display latent relativism (table 3).

\section{Table 3 Comparative methodology of some economic theories}

\begin{tabular}{|c|c|c|c|c|c|}
\hline & $\begin{array}{l}\text { Theory of } \\
\text { welfare }\end{array}$ & $\begin{array}{l}\text { Theory of } \\
\text { public goods }\end{array}$ & $\begin{array}{l}\text { Theory of } \\
\text { merit goods }\end{array}$ & $\begin{array}{l}\text { Concept of } \\
\text { mild } \\
\text { paternalism }\end{array}$ & $\begin{array}{l}\text { Theory of } \\
\text { patronized } \\
\text { goods }\end{array}$ \\
\hline \multirow[t]{2}{*}{$\begin{array}{l}\text { Individual } \\
\text { preferences }\end{array}$} & \multirow[t]{2}{*}{$\begin{array}{l}\text { Methodological } \\
\text { subjectivism }\end{array}$} & False signals & $\begin{array}{l}\text { Corrupted } \\
\text { signals }\end{array}$ & $\begin{array}{l}\text { Corrupted } \\
\text { signals }\end{array}$ & \multirow[t]{2}{*}{$\begin{array}{l}\text { Methodological } \\
\text { subjectivism }\end{array}$} \\
\hline & & $\begin{array}{l}\text { True } \\
\text { preferences }\end{array}$ & $\begin{array}{l}\text { True } \\
\text { preferences }\end{array}$ & $\begin{array}{l}\text { True } \\
\text { preferences }\end{array}$ & \\
\hline $\begin{array}{l}\text { Methodological } \\
\text { individualism / } \\
\text { methodological } \\
\text { relativism }\end{array}$ & $\begin{array}{l}\text { Methodological } \\
\text { individualism }\end{array}$ & $\begin{array}{l}\text { Latent } \\
\text { relativism }\end{array}$ & $\begin{array}{l}\text { Latent } \\
\text { relativism }\end{array}$ & $\begin{array}{l}\text { Latent } \\
\text { relativism }\end{array}$ & $\begin{array}{l}\text { Methodological } \\
\text { relativism }\end{array}$ \\
\hline $\begin{array}{l}\text { Normative } \\
\text { standard }\end{array}$ & $\begin{array}{l}\text { Revealed } \\
\text { preferences }\end{array}$ & $\begin{array}{l}\text { Preferences } \\
\text { of } \\
\text { samuelsonian } \\
\text { "ethics } \\
\text { expert" }\end{array}$ & $\begin{array}{l}\text { Value } \\
\text { perceptions }\end{array}$ & $\begin{array}{l}\text { Value } \\
\text { perceptions }\end{array}$ & $\begin{array}{l}\text { Normative } \\
\text { preferences of } \\
\text { society }\end{array}$ \\
\hline
\end{tabular}

In the theory of patronized goods with its axiomatic using combination of methodological subjectivism and methodological relativism, normative standard is defined based on normative interest of society in the shape of its preferences as an autonomous market subject. While individual preferences merging into market stream are averaged on the whole set of individuals, preferences of society as such that exist alongside with them do not undergo such reduction being defined by means of political system mechanisms. These interests are formed within two different institutional environments, thus they are not reducible to each other and are complimentary to each other. 
Thus, we speak here about two parallel processes, about market and political branches. One of them is solely connected with individual preferences and their harmonization with the help of market mechanism, while the other reflects the origin, expansion and actualization of normative interests of society by means of institutes of political system. Wherein, normative interests of socium, depending on the level of development of society and its political system, absorb the entire spectrum of public preferences based on socially approved values and ethic norms, ideas of justice and expediency, and other social directives. In other words, the field of public normative interests generated by political branch gets those value judgments that Samuelson in "Pure theory of public expenditures" attributed to his "ethics expert" and representatives of meritorics and mild paternalism called "true preferences." Note that the political branch is not a theoretical abstraction, it is real and observable process serviced by institutions of society. There participate certain individuals - "passionarities" - who define the "hot spots" of socium before others; mass media, public movements and parties that serve as "institutional lift" for the interests that have not obtained wide circulation; the representative organs of all levels that ultimately formulate the objectives variously correspondent with public expectations. It is this process that I consider the main formation mechanism of interests of society as such that finds a correspondent display in normative standard. By including into analysis' scope two branches of formation of public interest, we will have to reconsider one more assumption of economic theory.

\section{HETEROGENEITY PRINCIPLE}

Discussing the above stated question on the nature and mechanisms of formation of social entity interests in the Theory of patronized goods, I would like to support V.Polterovich's idea that it is not only about accepting their existence but also about concrete description of the political system that forms and actualizes these irreducible interests ${ }^{22}$. It is quite plausible that innuendos in this issue created a certain lack of understanding among some of my colleagues.

When I am considering the political branch of formation of public interest and ground their autonomy and irreducibility to the interests of individuals who take part in generating public interest elicited by market mechanism, I do not mean that normative interests are defines by some "mystic organ" or another abstraction. Of course not. As in the case of market branch of public interest, concrete people that interact with each other and with the existing institutions realize the formation of public normative interest. The problem however arises in defining whether these are the same people or different groups of individuals, the same institutions or different institutional environments immanent to each of the two branches of formation of public interest.

Here the content analysis begins that requires going back to initial assumptions. The standard axiom of homogeneity of economic agents and their preferences being one of them seems doubtful to many researchers. Let me quote G.Dosi, "It would be easier if we could justifiably represent the real "general equilibrium" (with multiple agents that are inhomogeneous at least in their initial resources and preferences) in compressed form as a representative agent. However, it is actually impossible. If we still do it against all the odds, we than suppose the coordination problem to be solved by construction" (Дози (2012, с. 35)). Though the statement about inhomogeneity of agents has an almost semi centennial history ${ }^{23}$, research papers in the main economic literature have been only recent addition.

\footnotetext{
22 For more detailed presentation of V.Polterovich's viewpoint expressed in our personal conversations see (Рубинштейн (2010, с. 111-116)).

${ }^{23}$ Apart from the studies devoted to the critics of general equilibrium models with "representative agent", let me point out some works in the are of economic and social psychology. For example, (Kelley,
} 
After the works of Nobel laureate James Heckman who demonstrated real opportunities for improvement of state policy by suggesting it acted in society with heterogenial agents and social groups with contrary interests, the assumption of heterogeneity began to be considered as a more adequate methodological principle (Heckman $(2001 a, b))$. The results of experiments including the sphere of public goods significantly corroborate to this conclusion (Fehr, Gachter (2000), Webley et al. (2001), Fischbacher et al. (2001), Andreoni, Miller (2002), Goeree et al. (2002)). Noteworthy is also a recent research by P.Orekhovsky devoted to the analysis of homogeneity axiom applied to economic agents, consumer preferences, production functions and public choice, in which he demonstrates an evident remoteness of "of this prerequisite from a modern economic reality"(Ореховский $(2013$, с. 31$)$ ). Essentially, we have here a similar situation to that observed above when analyzing the principle of rational behavior, where empirical studies of behavioral economists became the impetus for a critical assessment. In this case, the above-mentioned experiments as well as the case studies of sociologists and political scientists, repeatedly demonstrated the existence of social groups whose interests and the behavior of their members differ significantly from each other. P.Orekhovsky actually points out this almost commonplace fact, "Political (and sociological) analysis assumes that the interests of the various groups may be the opposite: some are interested in progressive taxation, others - in the "flat rate", some require free sales and the possibility to carry weapons, and others are strongly opposed. This is not simply "different preferences", these are different goals and values" (Ореховский (2013, с. 19-20)). The overall conclusion is also fair: the most important for the mainstream theory assumption of homogeneity of preferences in combination with methodological individualism, as well as the principle of rational behavior, discussed above, suffer from one affliction - "detachment from reality". Given this conclusion, it makes sense to consider how this issue is solved in the analyzed theories of public welfare, public and merit goods, and concept of libertarian or mild paternalism. It is clear that certain integrity and self-sufficiency of the public welfare theory that considers irrational individual behavior only in the line of market flaws and state failures; do not require either "doublethink", or normative standard, or two branches of public interest formation. The condition of homogeneity of economic agents and their preferences in combination with methodological individualism and the principle of rationality enables the construction of equilibrium models with optimum allocation of resources and the highest possible realization of social welfare. However, as before, it is necessary to state that this theory does not explain the many empirical facts displayed in the experiments of behavioral economists. Analysis of the theory of public goods, in which "normative standard" is defined by samuelsonian "ethics expert", located at will of Samuelson outside economy ${ }^{24}$, suggests that a not quite standard condition of heterogeneity is implicitly used here. It directly follows from the fact that "ethics expert" and individuals who consume public goods are different economic agents in this theory and have dissimilar preferences. And although Samuelson said nothing about heterogeneity assumption and, conversely, uses the "default" condition of homogeneity of aggregated consumers of public goods and their preferences, the mere existence of an "ethics expert" makes you think about the heterogeneity of economic agents. As for meritorics and the concept of mild paternalism, here, apparently, we face the same "default" use of heterogeneity condition as in the theory of public goods. The thing is that both meritorious, and libertarian paternalism presuppose state intervention in individuals' preferences. In other words, regardless the definition of normative standard, in all forms of "true preferences" identification it is admissible, or rather necessary in both concepts to push individuals by the external entity towards "right solutions".

Staheliski (1970a), Johnson, Nohrem-Hebeisem (1979), Andreoni (1995), Offerman et al. (1996), Burlando, Hey (1997), Burlando, Webley (1999)).

${ }^{24}$ Let me emphasize that Paul Samuelson took out the solutions of "expert on ethics" beyond economics and believed that they were not economic task (Самуэльсон (2004, с. 375)). 
Therefore in this case, de facto the assumption of heterogeneity is used that allows to divide the whole set of economic agents into two homogeneous groups with different preferences. In this sense, the theory of public goods, meritorics, and the concept of libertarian or soft paternalism are special cases of the Theory of patronized goods, where the explicitly formulated principle of heterogeneity belongs to the main methodological provisions. We can also state that, in accordance with the Theory of patronized goods, the interests generated by the political branch are principally inadequate to the interests formed by the market environment, and they cannot be defined in terms of market preferences. The vast majority of people do not possess such interests. Only a statistically irrelevant part of society - those whom Plato called "philosophers" (Платон (1971, m. 3, с. 275)), Musgrave attributed to the "informed group of people" (Musgrave (1969, s. 16)), and Schmidt classified as "politicians" (Schmidt (1988, s. 384)) are able to acknowledge these interests. The presence of this special group of people providing their articulation requires the mitigation of excessively rigid prerequisite of homogeneity of economic agents and their preferences.

Assuming the heterogeneity of economic entities, we can suppose the existence of at least two major groups - "individuals" who generate public interest through the market mechanism, and "politicians" whom the rest of the population entrusted to take care of the general welfare. ${ }^{25}$ To this, I would like to add a very important point of C. Taylor, "Living in society and, especially, studying its work, one should acknowledge such phenomena that are neither human nor their combinations: roles, responsibilities, status, rights, laws, customs "(Тейлор (2001, с. 7-8)). Therefore, if we can talk about participation of other citizens in the formation of public interest generated in the political environment, it can only be indirect, meaning political institutions and mechanisms of entrusting politicians with voters' opinions.

Considering in the Theory of patronized goods the political branch of formation of public interest and the "politicians" who generate normative attitudes of society and the corresponding normative standard, we should keep in mind a principally "different behavior" of this group of economic agents in relation to completely "different events" ${ }^{26}$. Let me explain what I mean by "politicians", "different events" and "different behavior". First, we are talking about a democratic society and its institutions, including the parliament, whose members based on an established procedure "define" normative interests of society and their current priorities ${ }^{27}$. Clearly, the concurrence of the two sets of individuals operating in the market and political environments is only possible when replacing parliamentary procedure with referendum. Taking into account the fact that the referendum itself is a rare exception to the standard of civil practice, we can assume that in the current discourse the only meaningful behavior is one of "politicians".

\footnotetext{
${ }^{25}$ In a well-known experiment with public goods the existence of " three types of players" is assumed , in particular, "free riders, cooperators and manipulators" (Burlando, Guala ( 2005 , p . 35) ). Here is another example. Recalling the work of Daron Acemoglu (Acemoglu ( 2007)), in which questions of "survivability of inefficient economic and political institutions" are researched, A. Radygin and R. Entov indicate that in the used models other three group of players are considered " 1 ) representatives of some abstract " elite" (apparently, a group of representatives of the ruling political elite ), 2) the middle class, trying to resist the "elite" ; 3) employees" (Радыгин, Энтов (2012, с. 17)).

${ }^{26}$ In my earlier works, I used the concept of "other people" with "different behavior" in relation to "different events" (Рубинштейн $(2011,2012))$. Following the principle of heterogeneity, the concept of "other people" can be replaced by a more appropriate category - "politicians", whose preferences differ from the preferences of individuals.

${ }^{27}$ In the preface to the English-language translation of Knut Wicksell's edition of the book "Study on the theory of finance" James Buchanan urged "fellow economists first to build any model of government or political system, and only then begin to analyze the results of government activities"» (Бьюкенен (1997, с. 18)). Following this methodologicaldirective and in order to analyze formation of public interest, I consider a fairly simple model of parliamentary democracy.
} 
Secondly, if an individual in market environment assesses available alternatives from the standpoint of their own benefit ${ }^{28}$, political branch generates alternatives related to normative understanding of public welfare. In this respect, it really is about "different events." For example, if in market environment individual decides on whether to go to the theater or buy apples, in the political environment "politicians" face another alternative: whether to support the exposure of the population to the theatrical art, or whether fruit consumption more important for society. It is clear that the identity of these alternatives is also possible only in the case of a referendum on the consumption of each good. That is why we can conclude that in the political process of public interests formation usually the "different events" are viewed.

Third, the Theory of patronized goods considers "different behavior" as the preferences of "politicians" acting on behalf of society, are mainly determined not by personal but public media. In addition, no matter how much we talk about the possible self-identification of the selected people with society, on behalf of which they form a normative standard and take appropriate decisions, it is still not the same as when individual has to pay for the consumed benefits by refusal to personally consume other benefits. Many studies indicate the possibility of lower evaluation of the usefulness of public resources for elected people in relation to their own resources ${ }^{29}$. In this sense, even a referendum cannot fix the "genetic defect" of public resources, which, in fact, determines the phenomenon of "different behavior".

I needed such lengthy explanations to clarify once more the mechanisms of formation of public normative interest - one of the most important provisions of the Theory of patronized goods. Using the heterogeneity principle as inter alia the basis for explaining "different behavior" and "politicians," I wanted to show that in the general case of the proposed model with two branches of public interests formation there is no place for dualism of preferences of the same individuals. We are talking about two sets of people, about fundamentally different public interests defined in the market and political environments, about their irreducibility to each other (table 4).

\section{Table 4 The principle of homogeneity in methodology of some economic theories}

\begin{tabular}{||l|l|l|l|l|l||}
\hline & $\begin{array}{l}\text { Theory of } \\
\text { welfare }\end{array}$ & $\begin{array}{l}\text { Theory of } \\
\text { public goods }\end{array}$ & $\begin{array}{l}\text { Theory of } \\
\text { merit goods }\end{array}$ & $\begin{array}{l}\text { Concept of } \\
\text { mild } \\
\text { paternalism }\end{array}$ & $\begin{array}{l}\text { Theory of } \\
\text { patronized } \\
\text { goods }\end{array}$ \\
\hline $\begin{array}{l}\text { Heterogeneity/ } \\
\text { homogeneity }\end{array}$ & Homogeneity & $\begin{array}{l}\text { Heterogeneity } \\
\text { "by default" }\end{array}$ & $\begin{array}{l}\text { Heterogeneity } \\
\text { "by default" }\end{array}$ & $\begin{array}{l}\text { Heterogeneity } \\
\text { "by default" }\end{array}$ & Heterogeneity \\
\hline $\begin{array}{l}\text { Market branch } \\
\text { of formation } \\
\text { of public } \\
\text { interest }\end{array}$ & $\begin{array}{l}\text { Market } \\
\text { aggregate of } \\
\text { individual } \\
\text { preferences }\end{array}$ & $\begin{array}{l}\text { Market } \\
\text { aggregate of } \\
\text { individual } \\
\text { preferences }\end{array}$ & $\begin{array}{l}\text { Market } \\
\text { aggregate of } \\
\text { individual } \\
\text { preferences }\end{array}$ & $\begin{array}{l}\text { Market } \\
\text { aggregate of } \\
\text { individual } \\
\text { preferences }\end{array}$ & $\begin{array}{l}\text { Market } \\
\text { aggregate of } \\
\text { individual } \\
\text { preferences }\end{array}$ \\
\hline $\begin{array}{l}\text { Political } \\
\text { branch of } \\
\text { formation of } \\
\text { public interest }\end{array}$ & Not available & $\begin{array}{l}\text { Preferences } \\
\text { of "ethics } \\
\text { expert" }\end{array}$ & $\begin{array}{l}\text { Value } \\
\text { judgments on } \\
\text { "true } \\
\text { preferences" }\end{array}$ & $\begin{array}{l}\text { Value } \\
\text { judgments on } \\
\text { "true } \\
\text { preferences" }\end{array}$ & $\begin{array}{l}\text { Normative } \\
\text { preferences } \\
\text { of society }\end{array}$ \\
\hline
\end{tabular}

Whiler researching such a category as the interest of social entity, one cannot but pay attention to the differences in the nature of individual and group interests. It should be said that this problem has

\footnotetext{
${ }^{28}$ Following Margolis I'm also willing to expand the boundaries of the Smithonian selfishness, and so far that altruism turns into component of rational behavior (Margolis $(1982$, p.17)). Note that in this formulation, the market branch of the formation of public preferences"captures" the altruistic interests of individuals.

${ }^{29}$ I will note that the end of the century was crowded with references to "rent-searching class", "political income", "bureaucratic rent", "logrolling", etc.
} 
never been very popular among economists. If it is present in the economic analysis, it is only in a small number of works and more on a "tangential" scale ${ }^{30}$.

The main subject after the fundamental work of Arrow on the public choice theory (Arrow (1951)), was the construction of general solutions (formation of social preferences), which have, by definition, the same properties as the preferences of individuals. Moreover, the theory itself with its reliance on methodological individualism and homogeneity of economic agents failed to expand the boundaries of economic analysis. Based on the fact that the public interest is merely an aggregate of (a combination) the interests of individuals, it actually postulates their equally positive nature, leaving out the interests of social entity which have normative content. It should be noted also that the ever existent desire to free the economic theory from value concepts, bring it closer to mathematics and make a positive science ${ }^{31}$ led to the fact that the category of normative interests was practically driven from economic analysis - there is no place for normative categories where only "rigor and consistency" are recognized (Кэц̆ $(2012, c$. 7)). Meanwhile without normative interests it is simply impossible to account for many processes. Therefore, expanding the boundaries of the traditional interpretation of group interest seems to me a very important step towards building an adequate economic methodology. To the group aggregate of individual preferences that along with individual interests are of positive nature, we should add the preferences of the group as such with the invariably standard nature. Let me also note that the normative character of social group interest as a whole is neither a hypothesis, nor a postulate. Regardless of the mechanisms of formation of such interest - whether it is a personal decision of a group leader or a choice of the coalition of like-minded (a party), or voting of all members of the group, it is always defined in the form of value judgments. Discussing methodological issues of Theory of patronized goods that include the normative interest of society and "likening" the state to the market subject that realizes this interest, we cannot but forget the verdict of R.Boudon, who emphasized that such assumptions were correct only in the case when the subject "... is endowed with institutional forms that allow it taking collective decisions "(Boudon (1979)). Thus, a clear and quite feasible requirement to the state -market subject is the presence of some institutional system that would allow making decisions on behalf of society. Basically, we are talking about another aspect of the considered methodology - the political structure of the state and civil society institutions, enabling collective decisions. This raises another important issue connected with the premise of the heterogeneity of economic agents. The fact is that in general case it makes sense to consider a variety of social groups and their authentic representatives, a certain part of which is in accordance with the institutions of the political system defines a set of "politicians" who express the corresponding group interests. Considering this, one should take into account the fact that "politicians" themselves are not a homogeneous group. Therefore, normative public interest generated by political branch, should be considered only as a democratic compromise formed during discourse determined by the current political system and the existing institutional environment capable both to approach and to distance public choice from social needs. One can only agree that "the political process has its own logic, which in many cases does not coincide with the habitual logic of optimizing economic mechanisms" (Радыгин, Энтов (2012, с. 26)). In other words, the political branch actualizes only the interests that are ready to be recognized by the political system itself, i.e. the complex of existing institutions and individuals in authority. It is these interests, regardless of their proximity to the real public needs, become by definition the normative public interests. Although the mechanisms of "social immunity" eventually make their adjustments by "correcting" public choice (Гринберг,

\footnotetext{
${ }^{30}$ I mean publications on value directives of society and their reflection in the institutional theory. See also (Xapcarbu (2004)).

${ }^{31}$ This is the famous debate at the "Union social policy" council meeting in Vienna in 1909 and the "free from value judgments of social science" doctrine of the Weber-Zobmbart (Wertfreiheit) that retains its supporters until today.
} 
Рубинштейн (2000, с. 210)), it remains impossible to overcome the uncertainty factor. We are always dealing with some approximations of interests of society as such. It should be also noted that while in the recent past there dominated the concept of "benevolent state" whose activity was aimed at implementing the actual public interests, by the end of the twentieth century the thesis of the displacement of public choice and related policy decisions in favor of the ruling elites started playing an increasingly important part (Stigler (1971)). Jean- Jacques Laffont draws attention at this trend, by considering the "authentic adviser" of the ruling party, who offers the action programme, that increases party's benefits in the current economic and political situation" (Лаффон (2007, c. 22-23)). While agreeing with this trend, it should be emphasized that it would be wrong to assume the existence of the only possible or objectively better choice. It always lies in the field of normative decisions, with the main role played by social attitudes and targets of the ruling party or coalition that has a majority in the parliament. It is their decisions that transform public interest into a normative interest formulated by the group of people with appropriate authority. One way or another, subjectivity is always present in determination of normative interest, which a number of authors explain with the phenomenon of "principal-agent": the real policy makers (agents) can have their preferences that do not coincide with the preferences of voters (the principal) on whose behalf they act (Афониев (2010)) ${ }^{32}$. In addition, it is not just about parliament's representability or organization of its work. Due to the heterogeneity of society, normative interest formulated by the ruling party will always differ from the real needs of society. It refers to any "collective decisions". Therefore, while discussing the methodological aspects of the Theory of patronized goods we should bear in mind the possibility of the development of civil society institutions that under conditions of uncertainty of public interests are able to reduce the deviation from the public interests articulated by politicians. Laffont offered a partial solution to the problem coming up with what he called as "a complete constitution approach"(Лаффон (2007, с. 29)). These, of course, are not the regulatory mechanisms of the public normative interests' formation, yet only certain frameworks that restrict political decisions. Sharing a common skepticism as for the adequacy of policy decisions, I assume that is very difficult, if not unreal to overcome this state of affairs in the absence of appropriate channels of expression opinions and demands of different social groups as well as legitimate opportunities to assert their rights. Therefore it is impossible not to think of adequate democratic institutions that reflect the interests of different social groups at the same level as the civil society is developed with its mechanisms of self-organization, which form these groups and generate relevant interest groups (Posnett (1987), Rose-Ackermann (1996), Salamon,

Hems, Chinnock (2000), Аузан, Тамбовцев (2005), Гражданское... (2011)).

$* * *$

Comparative analysis of methodology of the discussed theoretical constructions allows drawing the general conclusions of the research. First, it is possible to state that the Theory of the patronized goods is based on three basic assumptions: "methodological subjectivism", "methodological relativism" and "heterogeneity principle". They are integrated in this theory, first, in the form of supposition that every person depending on the level of his understanding and his value judgments acts subjectively optimally in the given circumstances; second, in the principle of utility complementarity, according to which there may be a group interest alongside with the individual interests of the group members; and third, in the form of two irreducible to each other branches of formation of public interest - market and political.

Second, analysis of basic premises of the Theory of public and merit goods, as well as the concept of libertarian paternalism gives ground for supposing that methodologically these theories are the particular cases of the Theory of patronized goods. Direct comparison of the initial premises speaks in favor of this hypothesis (table 5).

\footnotetext{
${ }^{32}$ A more general explanation is present in the works for a new political economy. See (Persson, Tabellini (2005), Либман (2007, 2008)).
} 
A close look at the data in the table shows that apart from the principle of "methodological subjectivism" all other initial premises and their consequences with the accuracy of general formulations are the same in all compared theoretical constructions. Moreover, as shown in the proceeding analysis, it is the use of the principle of multiplicity of "Self" that actually leads to some lack of explicitness of other initial premises and their consequences in the theory of public and merit goods and in the concept of libertarian or mild paternalism. It only remains to say that the principle of multiplicity of "Self" itself can be viewed as a particular case of the "methodological subjectivism". The thing is that the model with "multiple "Self" also supposes that each of these "Selves" act subjectively optimally.

\section{Table 5 Basic premises and their consequences in some economy theories}

\begin{tabular}{|l|l|l|l|l|l||}
\hline Theory of & $\begin{array}{l}\text { Theory of } \\
\text { public goods }\end{array}$ & $\begin{array}{l}\text { Theory of } \\
\text { merit goods }\end{array}$ & $\begin{array}{l}\text { Concept of } \\
\text { mild } \\
\text { paternalism }\end{array}$ & $\begin{array}{l}\text { Theory of } \\
\text { patronized } \\
\text { goods }\end{array}$ \\
\hline $\begin{array}{l}\text { Methodological } \\
\text { subjectivism/ } \\
\text { principle of } \\
\text { multiplicity of } \\
\text { "Self" }\end{array}$ & $\begin{array}{l}\text { Rationality } \\
\text { principle }\end{array}$ & $\begin{array}{l}\text { Principle of } \\
\text { multiplicity of } \\
\text { "Self" }\end{array}$ & $\begin{array}{l}\text { Principle of } \\
\text { multiplicity of } \\
\text { "Self" }\end{array}$ & $\begin{array}{l}\text { Principle of } \\
\text { multiplicity of } \\
\text { "Self" }\end{array}$ & $\begin{array}{l}\text { Methodological } \\
\text { subjectivism }\end{array}$ \\
\hline $\begin{array}{l}\text { Methodological } \\
\text { relativism/ } \\
\text { methodological } \\
\text { individualism }\end{array}$ & $\begin{array}{l}\text { Methodological } \\
\text { individualism }\end{array}$ & $\begin{array}{l}\text { Latent } \\
\text { relativism }\end{array}$ & $\begin{array}{l}\text { Latent } \\
\text { relativism }\end{array}$ & $\begin{array}{l}\text { Latent } \\
\text { relativism }\end{array}$ & $\begin{array}{l}\text { Methodological } \\
\text { relativism }\end{array}$ \\
\hline $\begin{array}{l}\text { Heterogeneity/ } \\
\text { homogeneity }\end{array}$ & Homogeneity & $\begin{array}{l}\text { Heterogeneity } \\
\text { "by default" }\end{array}$ & $\begin{array}{l}\text { Heterogeneity } \\
\text { "by default" }\end{array}$ & $\begin{array}{l}\text { Heterogeneity } \\
\text { "by default" }\end{array}$ & Heterogeneity \\
\hline $\begin{array}{l}\text { Market branch } \\
\text { of formation of } \\
\text { public interest }\end{array}$ & $\begin{array}{l}\text { Market } \\
\text { aggregate of } \\
\text { individual } \\
\text { preferences }\end{array}$ & $\begin{array}{l}\text { Market } \\
\text { aggregate of } \\
\text { individual } \\
\text { preferences }\end{array}$ & $\begin{array}{l}\text { Market } \\
\text { aggregate of } \\
\text { individual } \\
\text { preferences }\end{array}$ & $\begin{array}{l}\text { Market } \\
\text { aggregate of } \\
\text { individual } \\
\text { preferences }\end{array}$ & $\begin{array}{l}\text { Market } \\
\text { aggregate of } \\
\text { individual } \\
\text { preferences }\end{array}$ \\
\hline $\begin{array}{l}\text { Political branch } \\
\text { of formation of } \\
\text { public interest }\end{array}$ & Not available & $\begin{array}{l}\text { Preferences of } \\
\text { "ethics } \\
\text { expert" }\end{array}$ & $\begin{array}{l}\text { Value } \\
\text { judgments on } \\
\text { "true } \\
\text { preferences" }\end{array}$ & $\begin{array}{l}\text { Value } \\
\text { judgments on } \\
\text { "true } \\
\text { preferences" }\end{array}$ & $\begin{array}{l}\text { Normative } \\
\text { preferences of } \\
\text { society }\end{array}$ \\
\hline $\begin{array}{l}\text { Motivation of } \\
\text { state intervention }\end{array}$ & $\begin{array}{l}\text { Correction of } \\
\text { "market } \\
\text { failures" }\end{array}$ & $\begin{array}{l}\text { Definition of } \\
\text { volume of } \\
\text { public goods }\end{array}$ & $\begin{array}{l}\text { Pushing } \\
\text { towards } \\
\text { realization of } \\
\text { "true } \\
\text { preferences" }\end{array}$ & $\begin{array}{l}\text { Pushing } \\
\text { towards } \\
\text { realization of } \\
\text { "true } \\
\text { preferences" }\end{array}$ & $\begin{array}{l}\text { Realization of } \\
\text { public } \\
\text { normative } \\
\text { interest }\end{array}$ \\
\hline
\end{tabular}

Third, it is not hard to see that at least in three of its premises the Theory of patronized goods is close to evolutionary paradigm, which regards economic phenomena as "results of unequal interactions of limitedly rational, heterogenial agents with endogenial preferences...with their own understanding of the world and available behavioral models" (Дози $\left(2012\right.$, с. 31, 40)). ${ }^{33}$

Fourth, the expansion of the boundaries of economic analysis in the result of easing of too strict premises of neoclassic theory and change of the rationality axioms, methodological individualism and homogeneity with a more general ontology centered on "methodological subjectivism",

\footnotetext{
${ }^{33}$ For more about the research statement of evolutionist see also (Dosi, Orsenigo (1988), Dosi, Nelson (1994), Нельсон, Уинтер (2002), Dosi et al (2005)).
} 
"methodological relativism" and "heterogeneity principle" 34 with regard of the generalized WiksellLindahl equilibrium model for patronized goods built upon the stated principles (Рубинштейн $(2009 b, 2011,2012))$, allows viewing the Theory of patronized goods as the next evolutionary stage of Economy welfare theory. We speak here about formation of Normative theory of public welfare.

\footnotetext{
${ }^{34}$ In this context let me draw attention to the research of O.Ananyin "Ontological premises of economic theories" (Ананьин (2013)). In his report delivered at the seminar "Theoretical economy", Ananyin notes that ".. within the body of economic knowledge there developed the research programs with their own "hard cores", in fact, ontologies, the irrefutable within the framework of research program sets of basic premises" (Ананьин (2013, с. 18)). In the annotation to this report author calls such ontologies particular.
} 


\section{REFERENCES}

Автономов В.С. Модель человека в экономической теории и других социальных науках. М.: Изд. дом. ГУ-ВШЭ, 1998.

Автономов В.С. Абстракция - мать порядка? // Вопросы экономики. 2013. №4

Ананьин О.И. Онтологические предпосылки экономических теорий. М.: ИЭ РАН, 2013.

Ансар П. Современная социология // Социологические исследования. 1995. №12; 1996. №12, 7-10; 1997. №7.

Аузан А.А., Тамбовцев В.И. Экономическое значение гражданского общества // Вопросы экономики. 2005, №5.

Афонцев С.А. Политические рынки и экономическая политика. М.: КОМКНИГА, 2010.

Белянин А. Дэниел Канеман и Вернон Смит: экономический анализ человеческого поведения (Нобелевская премия за чувство реальности) // Вопросы экономики. 2003. №1. С. 4-23.

Блауг М. Методология экономической науки, или как экономисты объясняют / Пер. с англ.; Науч. ред. и вступ. ст. В.С. Автономова. М.: «НП “Журнал Вопросы экономики”», 2004.

Болдырев И. Языковые игры и экономическая теория мейнстрима. М., 2008.

Будон Р. Теория социальных изменений (пер. с англ.) / Под ред. М. Черныша. М.: АспектПресс, 1999.

Бхаскар Р. Общества / Пер. с англ. // Социо-логос. Вып. 1. М.: Прогресс, 1991.

Бьюкенен Дж. Конституция экономической политики // Нобелевские лауреаты по экономике. Джеймс Бьюкенен. М.: Таурус Альфа, 1997.

Вебер М. Исследования по методологии наук. М.: ИНИОН, 1980.

Вебер М. Избранное. Образ общества / Пер. с нем. М., 1994.

Верлен Б. Объективизм Поппера и метод критического рационализма» / Пер. с англ. // Социологическое обозрение. 2002. Т. 2. № 4.

Витгенштейн Л. Логико-философский трактат / Пер. с нем. М., 1958 (2009).

Витгенштейн Л. Философские работы / Пер. с нем. Ч. І. М., 1994.

Вольчик В.В. «Затерянный мир» австрийской экономической теории // Экономический вестник Ростовского государственного университета. 2007. Т. 5. №3.

Гофман А.Б. Эмиль Дюркгейм в России: рецепция дюркгеймовской социологии в российской социальной мысли. М.: ГУ ВШЭ, 2001.

Гражданское общество: зарубежный опыт и российская практика. [Сб. науч. ст.] / РАН, Институт экономики; ред. А. Лебедев. А. Ру бин штейн. СПб.: Алетейя, 2011.

Гринберг Р.С., Рубинштейн А.Я. Экономическая социодинамика. М.: ИСЭПРЕСС, 2000.

Гринберг Р.С., Рубинштейн А.Я. Основания смешанной экономики. Экономическая социодинамика. М.: ИЭ РАН, 2008.

Гринберг Р.С., Рубинштейн А.Я. Теория, инновации и контуры будущей экономики в диалоге с Кеннетом Эрроу // Вопросы экономики. 2010. №10.

Де Сото. У.Х. Сущность австрийской школы (Лекция). Государственный университет Высшая школа экономики. Москва 30 октября 2008 г.

Де Сото У.Х. Австрийская экономическая школа: рынок и предпринимательское творчество (пер. с англ. Б.С. Пинскера под ред. А.В. Куря ева). Челябинск: Социум, 2009.

Дози Дж. Экономическая координация и динамика: некоторые особенности альтернативной эволюционной парадигмы // Вопросы экономики. 2012. №12.

Дэвидсон Д. Исследование истины и интерпретации. М.: Праксис, 2003.

Дюркгейм Э. Метод социологии. Киев-Харьков, 1899.

Заостровцев А.П. Австрийская школа экономической мысли // Вестник Удмуртского университета. 2007. №2.

Канеман Д., Тверски А. Рациональный выбор, ценности и фреймы // Психологический журнал. 2003. Т. 24. №4. 
Коландер Д. Революционное значение сложности и будущее экономической науки // Вопросы экономики. 2009. №1.

Крозье М. Современное государство - скромное государство. Другая стратегия изменения // Свободная мысль. 1993. №11.

Кэй Дж. Карта - не территория: о состоянии экономической науки // Вопросы экономики. 2012. №5.

Лаффон Ж.-Ж. Стимулы и политэкономия / Пер. с англ. М.: Изд. дом ГУ-ВШЭ, 2007.

Лещак О.В. Очерки по функциональному прагматизму: Методология -онтология эпистемология. Тернополь-Кельце: Підручники \& посібники, 2002.

Либман А.М. Экономическая теория и социальные науки об экономике: некоторые направления развития. М.: ИЭ РАН, 2007.

Либман А.М. Политико-экономические исследования и современная экономическая теория. М.: ИЭ РАН, 2008.

Либман А.М. Социальный либерализм, общественный интерес и поведенческая экономика // Общественные науки и современность. 2013. № 1. С. 27-38.

Лившиц В.Н. Основы системного мышления и системного анализа. М.: ИЭ РАН, 2013.

Майерсон Р. Равновесие по Нэшу и история экономической науки // Вопросы экономики. 2010. №6.

Маршалл А. Принципы политической экономии. Т. I. М.: Прогресс, 1983.

Масгрейв Р., Масгрейв П. Государственные финансы: теория и практика / Пер. англ. М.: Бизнес Атлас, 2009.

Нельсон Р., Уинтер С. Эволюционная теория экономических изменений. М.: Дело, 2002.

Ольсевич Ю.Я. Современный кризис «мейнстрима» в оценках его представителей (предварительный анализ). М.: ИЭ РАН, 2013.

Ореховский П.А. Посылка однородности экономических агентов: парадоксы теории и практики. М.: ИЭ РАН, 2013.

Павлов И.А. Поведенческая экономическая теория - позитивный подход к исследованиям человеческого поведения. М.: ИЭ РАН, 2007.

Павлов И.А. Феномен «уклонения от двусмысленности» в теории рационального выбора. М.: ИЭ РАН, 2011.

Платон. Государство / Платон. Собр. соч. в 3 тт. М., 1971.

Полтерович B.M. Кризис экономической теории // Экономическая наука современной России. 1998. №1.

Полтерович В.М. Становление общего социального анализа // Общественные науки и современность. 2011. №2.

Поппер К. Время лжепророков: Гегель, Маркс и другие оракулы: В 2 т. Т. 2. Открытое общество и его враги. М., 1992.

Радыгин А., Энтов Р. Провалы государства»: теория и политика // Вопросы экономики. 2012. №12.

Рубинштейн А.Я. К теории рынков «опекаемых благ» // Доклад на Секции экономики Отделения общественных наук РАН, 25 марта 2008 г.

Рубинштейн А.Я. К теории рынков опекаемых благ. Статья 1. Опекаемые блага и их место в экономической теории // Общественные науки и современность. 2009а. №1.

Рубинштейн А.Я. К теории рынков «опекаемых благ». Статья 2. Социодинамическое описание рынков опекаемых благ // Общественные науки и современность. 2009б. №2.

Рубинштейн А.Я. Мериторика и экономическая социодинамика: дискуссия с Р. Масгрейвом // Вопросы экономики. 2009с. №11.

Рубинштейн А.Я. Рождение теории. Разговоры с известными экономистами. М.: Экономика, 2010.

Рубинштейн А.Я. Опекаемые блага: институциональные трансформации // Вопросы экономики. 2011. №3. 
Рубинштейн А.Я. Социальный либерализм: к вопросу экономической методологии // Общественные науки и современность. 2012. №6.

Саймон Г. Рациональность как процесс и продукт мышления // THESIS. 1993. Вып. 3.

Самуэльсон П. Чистая теория общественных расходов. // Вехи экономической мысли. Т. 4. Экономика благосостояния и общественный выбор / Пер. с анг. под общ. ред. А.П. Заостровцева. СПб: Экономическая школа, 2004.

Сапов Г. Значение австрийской школы экономики, ее эволюция и перспективы (стенограмма лекции). М.: ВШК, 1998 (www.sapov.ru/ staroe/si03.html).

Сокал А., Брикмон Ж. Интеллектуальные уловки. Критика современной философии постмодерна / Пер. с анг. А. Костиковой и Д. Кралечкина. М.: Дом интеллектуальной книги, 2002.

Соссюр Ф. де. Заметки по общей лингвистике. / Пер. с фр. М.: Прогресс, 2000.

Соссюр Ф. де. Курс общей лингвистики. М., 2009 (переиздание 1933 г.).

Стиглиц Дж. Крутое пике. Америка и новый экономический порядок после глобального кризиса. М.: Эксмо, 2011.

Тейлор Ч. Неразложимо социальные блага // Неприкосновенный запас. 2001. №4 (18).

Тихонова Н.Е. Социальный либерализм: есть ли альтернатива? // Общественные науки и современность. 2013. № 2. С. 32-44.

Урнов М.Ю. Социальный либерализм в России (взгляд политолога) // Общественные науки и современность. 2013. № 3. С. 30-43.

Фридман М. Методология позитивной экономической науки // THESIS. 1994. Вып. 4. С. 2052.

Харсаньи Дж. Ценностные суждения // Экономическая теория. М.: ИНФРА-М, 2004.

Ходжсон Дж. Институты и индивиды: взаимодействие и эволюция // Вопросы экономики. 2008. №8.

Хэндс У. Нормативная теория рационального выбора: прошлое, настоящее и будущее // Вопросы экономики. 2012. №10.

Эволюционная эпистемология и логика социальных наук: Карл Поппер и его критики / Составление Д. Г. Лахути, В. Н. Садовского и В. К. Финна М.: Эдиториал УРСС, 2000.

Acemoglu D. Modeling Inefficient Institutions // Advances in Economic Theory. Proceedings of the World Congress 2005. Cambridge, MA: Cambridge University Press, 2007.

Agassi J. Methodological individualism // The British Journal of Sociology, 1960. Vol. 11. No. 3. P. 244-270.

Agassi J. Methodological Individualism // Modes of Individualism and Collectivism. Ed. by J. O’Neill. L., 1973.

Andel N. Zum Konzept der meritorischen Guter // Finanzarchiv. 1984.Vol. 42.

Andreoni J. (1995). Cooperation in public-goods experiments: Kindness or confusion? // American Economic Review. 1995. Vol. 85. No. 4.Pp. 891-904.

Andreoni J., Miller J. Giving according to GARP: An experimental test of the consistency of preferences for altruism// Econometrica. 2002. Vol. 70(2). Pp. 70, 737-753.

Aoki M. Toward a comparative institutional analysis. Cambridge, MA, 2001.

Arrow K. Social Choice and Individual Values. Chicago: Univ. of Chicago, 1951.

Benabou R. Tax and education policy in a heterogeneous-agent economy: What levels of redistribution maximize growth and efficiency? // Econometrica. 2002. Vol. 70(2). Pp. 481517.

Bhaskar R. The possibility of naturalism: A philosophical critique of the contemporary human sciences. 2nd ed. Brighton: Harvester, 1989.

Boudon R. La logique du sociale: introduction a l'analyse sociologique. Paris: Hachette, 1979.

Boudon R. Individualisme ou holisme: un debat metodologique fondamental. In: Mendras H., Verret M. (eds.) Les Champs de la sociologie francaise. Paris: Armand Colin, 1988.

Brennan G., Lomasky L. Institutional Aspects of «Merit Goods» Analysis // Finanzarchiv. 1983. No. 41. S. 183-206. 
Buchanan J.M. Liberty, Market and State, Brighton. England: Wheatsheaf Books, 1986.

Burlando R., Hey J. Do Anglo-Saxons free-ride more? // Journal of Public Economics. 1997. Vol. 64. No. 1. Pp. 41-60.

Burlando R., Webley P. Individual differences in value orientation in the private provision of public goods. Inquiries into the Nature and Causes of Behaviour: Proceedings of the XXIV Colloquium of the International Association for Research in Economic Psychology. 1, Belgirate, Italy, 1999, 518-526.

Burlando R.M., Guala F. Heterogeneous Agents in Public Goods Experiments // Journal of Experimental Economics. April 2005. Vol. 8. Issue 1. Pp. 35-54.

Camerer C., Issacharoff S., Loewenstein G., O'Donaghue T., Rabin M. Regulation for Conservatives: Behavioral Economics and the Case for 'Asymmetric Paternalism' // University of Pennsylvania Law Review. 2003. Vol. 151. Pp. 1211-1254.

D’Amico D. Merit Goods, Paternalism and Responsibility, mimeo Universita di Pavia, 2009.

Dosi G., Orsenigo L. Coordination and Transformation: An Overview of Structures, Behaviours and Change in Evolutionary Environments Technical Change and Economic Theory / G. Dosi et al. (eds.). L.: Pinter; N. Y.: Columbia University Press, 1988.

Dosi G., Nelson R.R. An Introduction to Evolutionary Theories in Economics // Journal of Evolutionary Economics. 1994. Vol. 4. No. 3. Pp. 153-172.

Dosi G., Marengo L., Fagiolo G. Learning in Evolutionary Environments // The Evolutionary Foundations of Economics. Cambridge: Cambridge University Press, 2005.

Fehr Е., Gдсhter S. Cooperation and Punishment in Public Goods Experiments Source // The American Economic Review. 2000. Vol. 90. No. 4 (Sep., 2000). Pp. 980-994.

Fischbacher U., Gдchter S., Fehr E. Are People Conditionally Cooperative? Evidence from a Public Goods Experiment. Economics Letters. 2001, 71, 397-404.

Friedman M. The Methodology of Positive Economics. In: Friedman M. Essays in Positive Economics. Chicago: University of Chicago Press, 1953.

Giddens A. The Constitution of Society. Outline of the Theory of Structuration. Cambridge: Polity Press, 1984.

Giddens A. Sociology. Cambridge: Polity Press, 2001.

Goeree J., Holt C., Laury S. Private costs and public benefits: Unreavealing the effects of altruism and noisy behavior // Journal of Public Economics. 2002. Vol. 83, 255-276.

Grinberg R., Rubinstein A. Economic Sociodynamics. Berlin, New York: Springer, 2005 (reprinted 2010).

Head J.G. On Merit Goods // Finanzarchiv. 1966, 25.

Head J.G. On Merit Wants // Finanzarchiv. 1988, 46.

Heckman J. Micro-data, heterogeneity, and the evaluation of public policy: Nobel lecture // Journal of Political Economy. 2010a. Vol. 109, 673-748.

Heckman J. Accounting for heterogeneity, diversity, and general equilibrium in evaluating social programmes // The Economic Journal. 2010b. Vol. 111, 654-699.

Johnson D., Norem-Hebeisem A. A measure of cooperative, competitive, and individualistic attitudes // Journal of Social Psychology. 1979. Vol. 109, 253-261.

Kahneman D., Tversky A. (eds.). Choices, values and frames. New York: Cambridge University Press, 2000.

Kahneman D. Maps of Bounded Rationality: Psychology for Behavioral Economics // American Economic Review. 2003. Vol. 93. No. 5. P. 1449-1475.

Katona G. Psychological Analysis of Economic Behavior. NY: McGrow- Hill, 1951.

Kelley H., Staheliski A. Social interaction basis of cooperators' and competitors' beliefs about others // Journal of Personality and Social Psychology. 1970a, 16, 66-91.

Kelley H., Staheliski A. The inference of intention from moves in the Prisoner's Dilemma Game // Journal of experimental social psychology. 1970b, 6, 401-419.

Kincaid H. Methodological Individualism/Atomism // The Handbook of Economic Methodology. UK, London: Edwar Elgar Publishing Limited, 1998. 
Koboldt C. Okonomic der Versuchung; Drogenverbot und Sozialvertragstheorie, Tьbingen, 1995.

Kreuger A.O. The Political Economy of the Rent-Seeking Society // American Economic Review. 1974. Vol. 64.

Kreuger A. Government Failures in Development // Journal of Economic Perspectives. 1990. Vol. 4. P. 9-23.

Krimerman L. (ed.). The Nature and Scope of Social Science. A Critical Anthology. New York: Appleton-Century-Crofts, 1969.

Machlup F. Austrian Economics//Encyclopedia of Economics. New York: McGraw-Hill, 1982.

Margolis H. Selfishness, Altruism and Rationality: A Theory of Social Choice. Chicago and London, 1982.

Mayer T. Truth versus Precision in Economics. Aldershot, Brookfield, VT: Edward Elgar, 1993.

McLure C.E. Merit Wants: a Normatively Empty Box // Finanzarchiv. 1968, 27.

Menger C. Grundsatze der Volkswirtschaftslehre. 2. Aufl., Wien-Leipzig, 1923.

Mukoyama T. Macroeconomic Models of Heterogeneous Agents. University of Virginia / February 2008, Bank of Japan lectures.

Mbller Ch., Tietzel M. Merit goods from a constitutional perspective. In: Brennan G. et al. (eds.).

Method and morals in constitutional economics. Essays in honor of James M. Buchanan, Springer, Berlin \& New York, 2002, 375-400.

Musgrave R.A. The Theory of Public Finance. N.Y.; London: McGraw-Hill, 1959.

Musgrave R.A. Provision for Social Goods. In: Margolis J., Guitton H. (eds.). Public Economics. London-Besingstoke: MacMillan, 1969.

Musgrave R.A, Musgrave P.B, Kullmer L. Die цffentlichen Finanzen in Theorie und Praxis, Band 1, 6. Auflage, Tьbingen, 1994.

Myrdal G. Objectivity in Social Research. London: Duckworth, 1970.

Offerman T., J. Sonnemans and A. Schram. Value orientations, expectations, and voluntary contributions in public goods // Economic Journal. 1996, 106, 817-845.

O’Neil J. (ed.). Modes of Individualism and Collectivism. London, 1973.

Persson T., Tabellini G. The Economic Effects of Constitutions. Cambridge: MIT Press, 2005.

Posnett J. Trends in the Income of Charities, 1980 to 1985. In: J. McQuillan (ed.). Charity Trends 1986/87. Tonbridge, Chanties Aid Foundation, 1987.

Priddat B.P. Zur Цkonomie der Gemeinschaftbedurfnisse: Neuere Versuche einer ethischen Begrsndung der Theorie meritorischen Guten // Zeitschrift fur Wirtschafts-und Sozialwissenschaften. 1992, 112.

Rhos-Rull J-V. Models with heterogeneous agents. Chapter 4. In:T. Cooley (ed.). Frontiers of Business Cycle Theory. Princeton University Press, 1995.

Rose-Ackermann S. Altruism, Nonprofits, and Economic Theory // Journal of Economic Literature. 1996. Vol. 34. No. 2. Pp. 701-728.

Salamon L., Hems L., Chinnock K. The Nonprofit Sector: For What and for Whom? Working Papers of the Johns Hopkins Comparative Nonprofit Sector Project. No. 37. Baltimore, The Johns Hopkins Center for Civil Society Studies, 2000.

Samuelson P.A. The pure theory of public expenditure // Review of Economics and Statistics. 1954. Vol. 36. No. 4.

Schaffle A.E.F. Das gesellschaftliche System der menschlichen Wirtschaft, 3. Aufl., 1. Band, Tubingen, 1873.

Schelling T. The intimate contest for self-command. In: Choice and Consequence: Perspectives of an errant economist. Cambridge: Harvard University Press, 1984.

Schmidt K. Mehr zur Meritorik. Kritisches und Alternatives zu der Lehre von den offentlichen Gutern // Zeitschrift fur Wirtschafts- und Sozialwissenschaften. 108. Jahrgang 1988.

Schneider W., Shiffrin R.M. Controlled and Automatic Human Information Processing: I. Detection, Search, and Attention // Psychological Review. 1977a. Vol. 84. No. 1. P. 1-66. 
Schneider W., Shiffrin R.M. Controlled and Automatic Human Information Processing: II. Perceptual Learning, Automatic Attending and a General Theory // Psychological Review. 1977b. Vol. 84. No. 2. P. 127-190.

Shefrin H.M., Thaler R. An Economic Theory of Self. Center for Economic Analysis of Human Behavior and Social Institutions. Working Paper. 1978. No. 208.

Shefrin H.M., Thaler R.H. An Economic Theory of Self-Control // Journal of Political Economy. 1981, 89.

Simon H.A. A Behavioral Model of Rational Choice // Quarterly Journal of Economics. 1955. Vol. 69. No. 1. P. 99-118.

Simon H.A. A Behavioral Model of Rational Choice. In: Models of Man, Social and Rational: Mathematical Essays on Rational Human Behavior in a Social Setting. New York: Wiley, 1957.

Smith V.L. Rational Choice: The Contrast between Economics and Psychology // Journal of Political Economy, University of Chicago Press. 1991. Vol. 99(4). Pp. 877-897.

Stigler G. The Theory of Economic Regulation // Bell Journal of Economics. 1971. Vol. 2(1).

Sturn R. «Public goods» before Samuelson: interwar Finanzwissenschaft and Musgrave's synthesis. Year: 2010.

Sugden R. Why incoherent preferences do not justify paternalism // Constitutional Political Economy. 2008. Vol. 19. Pp. 226-248.

Sunstein C., Thaler R. Libertarian paternalism is not an oxymoron. University of Chicago Law Review, 2003. Vol. 70. Pp. 1159-1202.

Sunstein C., Thaler R. Nudge: Improving Decisions about Health, Wealth, and Happiness. Yale University Press, 2008.

Thaler R.H. From Homo Economicus to Homo Sapiens // Journal of Economic Perspectives. 2000. Vol. 14. No. 1. Pp. 133-141.

Tietzel M., Muller C. Noch mehr zur Meritorik // Zeitschrift fur Wirtschafts - und Sozialwissenschaften. 1998. 118. Jahrgang. Heft 1.

Touraine A. Un nouveau paradigme. Pour comprendre le monde d'aujourd'hui. Paris, 2005.

Tullock G., Seldon A., Brady G. Government Failure: A Primer in Public Choice. Washington, DC: Cato Institute, 2002.

Verlen B. The objective perspective // Society, Action and Space. L.: Routledge, 1993.

Webley P., Burgoyne C.B., Lea S.E.G., Young B.M. The Economic Psychology of Everyday Life. Hove: Psychology Press, 2001.

Winston C. Government Failure versus Market Failure. Microeconomics Policy Research and Government Performance. Washington, DC: AEI-Brookings Joint Center for Regulatory Studies.

http://socioline.ru/pages/lektsiya-h-uerta-de-soto-suschnostavstrijskoj-shkoly.

http://www.economist.com/node/6768159. 